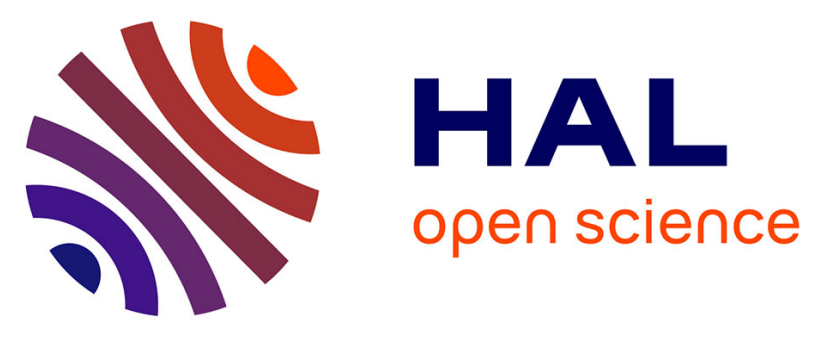

\title{
Copper(I) complexes with remotely functionalized phosphine ligands: synthesis, structural variety, photophysics and effect onto the optical properties
}

Julien Egly, Damien Bissessar, Thierry Achard, Benoît Heinrich, Pascal

Steffanut, Matteo Mauro, Stéphane Bellemin-Laponnaz

\section{To cite this version:}

Julien Egly, Damien Bissessar, Thierry Achard, Benoît Heinrich, Pascal Steffanut, et al.. Copper(I) complexes with remotely functionalized phosphine ligands: synthesis, structural variety, photophysics and effect onto the optical properties. Inorganica Chimica Acta Reviews, 2021, 514, pp.119971. 10.1016/j.ica.2020.119971 . hal-02998095

\section{HAL Id: hal-02998095 https://hal.science/hal-02998095}

Submitted on 10 Nov 2020

HAL is a multi-disciplinary open access archive for the deposit and dissemination of scientific research documents, whether they are published or not. The documents may come from teaching and research institutions in France or abroad, or from public or private research centers.
L'archive ouverte pluridisciplinaire HAL, est destinée au dépôt et à la diffusion de documents scientifiques de niveau recherche, publiés ou non, émanant des établissements d'enseignement et de recherche français ou étrangers, des laboratoires publics ou privés. 


\section{Copper(I) complexes with remotely functionalized phosphine ligands: synthesis, structural variety, photophysics and effect onto the optical properties}

by

Julien Egly, ${ }^{\mathrm{a}}$ Damien Bissessar, ${ }^{\mathrm{a}}$ Thierry Achard, ${ }^{\mathrm{a}}$ Benoît Heinrich, ${ }^{\mathrm{a}}$ Pascal Steffanut, ${ }^{\mathrm{b}}$ Matteo Mauro, *a Stéphane Bellemin-Laponnaz*a

a Institut de Physique et Chimie des Matériaux de Strasbourg, Université de StrasbourgCNRS UMR 7504, 23 rue du Loess, BP 43, 67034 Strasbourg cedex 2, France. Fax: +33 (0)388107246; Tel: +33 (0)388107166; E-mail: bellemin@unistra.fr, mauro@unistra.fr ${ }^{b}$ CLARIANT Plastics and Coatings AG, Rothausstrasse 61, 4132 Muttenz, Switzerland 


\begin{abstract}
The synthesis, chemical and photophysical investigation of a series of eight novel copperhalide derivatives with different nuclearity is herein presented. One mononuclear copper(I) complex with formula $\left[\mathrm{CuI}(\right.$ pyridine $\left.)(\mathrm{P})_{2}\right]$, where $\mathrm{P}$ is a functionalized phosphine, six dinuclear derivatives bearing the rhombic $\left\{\mathrm{Cu}_{2} \mathrm{I}_{2}\right\}$ subunits and with general formula $[\mathrm{Cu}(\mu$ $\mathrm{I})(\mathrm{P})(\mathrm{N})]_{2}(\mathrm{~N}=$ pyridine, quinoline and 4-cyanopyridine $)$ as well as one tetranuclear copperiodide clusters of general formula $[\mathrm{Cu}(\mu-\mathrm{I}) \mathrm{P}]_{4}$ consisting of a cubane-like $\left\{\mathrm{Cu}_{4} \mathrm{X}_{4}\right\}$ motif were straightforwardly prepared, also by means of mechano-chemical synthetic procedure. The phosphine ligands were prepared in excellent yield by using simple hydrophosphination reactions. For five of the investigated cuprous iodide derivatives their atom connectivity and solid-state crystalline packing was unambiguously confirmed by solving their single-crystal X-ray structure. All the investigated complexes resulted into photo- and thermally-stable luminescent species. In the solid state as microcrystalline powder samples, the complexes display intense photoluminescence ranging from the sky-blue to orange-red portion of the spectrum with PLQY values of $0.28-0.50$ and $0.34-0.97$ at room and low (77 K) temperature, respectively, depending on the nature of both the coordinated N-heteroaromatic ring and phosphine ligands. In spite of the remote location of the functionalization of the phosphine, profound effects are observed onto the solid-state emission properties highlighting the importance of microenvironment for the emitters in the aggregated phase.
\end{abstract}

\title{
Keywords
}

Copper complexes, cuprophilic interactions, photophysics, phosphine ligands, phosphorescence 


\section{Introduction}

Photoactive, earth-abundant, metal complexes are currently the subject of intensive research in inorganic photochemistry that is mainly driven by their appealing applications in the field of photocatalysis, solar energy conversion and light emitting devices [1-5]. In particular, $\mathrm{Cu}(\mathrm{I})$-based emitters are considered as an attractive alternative to those containing platinum group metals for the development of (electro-)luminescent materials [6-10]. Compared to these latter, copper is indeed less toxic and cheaper. Also, its luminescent complexes lack of low-lying metal centered (MC) states that might detrimentally affect the emission efficiency owing to the $\mathrm{d}^{10}$ electronic configuration of the $\mathrm{Cu}(\mathrm{I})$ ion. On the other hand, copper atom exerts a much smaller spin orbit coupling (SOC) effect compared to iridium and platinum $\left(\zeta_{\mathrm{Cu}}\right.$ $\left.=857 \mathrm{~cm}^{-1} ; \zeta_{\mathrm{Ir}}=3909 \mathrm{~cm}^{-1} ; \zeta_{\mathrm{Pt}}=4481 \mathrm{~cm}^{-1}\right)$, which significantly reduces the first-order perturbation associated with singlet-triplet mixing. As a consequence, it results that luminescent copper complexes typically possess slower radiative rate constants and longerlived excited states than those containing heavier metals. This makes the former less suitable for application in efficient solid-state light emitting devices at the current stage, since detrimental processes such as triplet-triplet annihilation (TTA) and exciton-polaron quenching may occur to a large extent. Nonetheless, increasing efforts are devoted to enhance the emission properties of copper-based emitters nowadays [11].

As function of the ligands surrounding the metal, temperature and aggregation state, $\mathrm{Cu}$ complex can exhibit emissions that are derived from different excited states, i.e. metal-toligand charge-transfer (MLCT), halide-to-ligand charge transfer (XLCT) and also clustercentered charge-transfer (CC) for polynuclear copper complexes [8,9,12]. Remarkably, some $\mathrm{Cu}(\mathrm{I})$ complexes have successfully displayed Thermally-Activated Delayed Fluorescence (TADF) and showed efficient singlet harvesting in Organic Light Emitting Diodes (OLEDs) $[11,13-16]$ 
As a matter of fact, copper(I) show propensity towards coordination with halogens and heteroaromatic ligands, including nitrogen, phosphorous and chalcogen-containing species, yielding a remarkable structural variety that is highly dependent on the employed synthetic procedure. Moreover, this class of emitters is characterized by rich polymorphism and colorful photophysics in the solid state, which is also strongly influenced by processing solvents and condition $[17,18]$. However, the high structural flexibility renders the selective preparation of copper-halide species often cumbersome.

Pioneering investigations on the luminescence of mononuclear copper complexes of general formula $\left[\mathrm{Cu}\left(\mathrm{N}^{\wedge} \mathrm{N}\right)_{2}\right]^{+}$, where $\mathrm{N}^{\wedge} \mathrm{N}$ is a chelating diimine ligand such as substituted phenanthrolines, were reported by the group of McMillin [19], which unrevealed emission from an higher-lying ${ }^{1} \mathrm{MCLT}$ state in thermal equilibrium with ${ }^{3} \mathrm{MLCT}$ manifold, [20,21] as well as the excited state quenching process through $D_{2}$ flattening and exciplex formation [22,23]. Recently, Kato and collaborators showed that simple TADF-active copper(I) halide complexes stabilized by triphenylphosphine ligand and various $\mathrm{N}$-aromatic ligands can be efficiently prepared from inexpensive reagents via mechanochemical syntheses in a rather straightforward manner [24-27].

Multinuclear cuprous compounds bearing heteroaromatic ligands have been largely investigated as well, which display either discrete or polymeric structure (formally) formed by the assembling of rhombic $\left\{\mathrm{Cu}_{2} \mathrm{X}_{2}\right\}$ subunits $(\mathrm{X}=$ halogen $)$ into linear or ladder-type structure that often display intense emission in the solid state. Though a few scattered reports describing the photophysics of dinuclear $\left\{\mathrm{Cu}_{2} \mathrm{X}_{2} \mathrm{~L}_{4}\right\}$ species, where $\mathrm{L}$ is a N- and/or P- ligand, were reported previously [28-31], the first extensive investigation was carried out by Sasaki, Tsuge and co-workers on compounds of the family $\left[\mathrm{Cu}(\mu-\mathrm{X})\left(\mathrm{PPh}_{3}\right) \mathrm{L}\right]_{2}$ and $\left[\mathrm{Cu}(\mu-\mathrm{X}) \mathrm{L}_{2}\right]_{2}$ with different ligand combinations $(\mathrm{L}=$ is pyridine/substituted pyridine or a saturated amine) $[12,32,33]$ that highlighted the effect of the halogen and $\pi$-accepting ability of the $\mathrm{N}$ - 
containing ligand on the nature of the emitting excited state. Following works by Kato and coworkers investigated the photoluminescence properties of the $\left[\mathrm{Cu}(\mu-\mathrm{X}) \mathrm{L}_{2}\right]_{2}$ scaffold bearing P- and S- ligands, [34-36] as well as of coordination polymers containing the dinuclear $\left\{\mathrm{Cu}_{2} \mathrm{X}_{2}\right\}$ scaffold [37,38]. In addition, Bräse described a novel family of highly luminescent either homo- or heteroleptic complexes consisting of a butterfly-shaped $\left\{\mathrm{Cu}_{2} \mathrm{X}_{2}\right\}$ skeleton and bearing various heteroaromatic $\mathrm{P}^{\wedge} \mathrm{N}$ bridging ligands $[15,39,40]$.

Furthermore, tetranuclear copper-iodide clusters of general formula $[\mathrm{Cu}(\mu-\mathrm{I}) \mathrm{L}]_{4}$ consisting of a $\left\{\mathrm{Cu}_{4} \mathrm{X}_{4}\right\}$ core and ligands located apically have attracted major attention because of their intriguing photophysics, including dual emission arising from two electronically decoupled excited states, namely a high-energy (HE) ${ }^{3} \mathrm{XLCT}$ state and lowenergy (LE) ${ }^{3} \mathrm{CC}$ one.[8] Since the pioneering investigation of Ford and co-workers on the family $[\mathrm{Cu}(\mu-\mathrm{I})(\mathrm{N})]_{4}(\mathrm{~N}=$ nitrogen containing ligand, e.g. pyridine) $[28,41,42]$ other groups investigated the effect of the nature of the ligand onto the photoluminescence, electroluminescence[43] as well as stimuli-responsive properties [44-46] of tetranuclear cuprous halide clusters $[\mathrm{Cu}(\mu-\mathrm{I})(\mathrm{P})]_{4}$ with phosphine ligands. Indeed, owing to their high structural flexibility, most copper-halide species are often emissive in the aggregated state only. Noteworthy, their emission is not only influenced by the nature of the coordination sphere around the metal atom, but tiny differences induced by the externally induced modulation of the $\mathrm{Cu} \cdots \mathrm{Cu}$ distances, molecular packing and chemical environment may have profound impact on the photophysical properties of these species [47-50].

An important motivation in developing copper(I) complexes is their low cost and their easy synthetic access using simple starting ligands, especially when considering their applications. Here, we investigated the potential of alternative and remotely-functionalized phosphine ligands that are obtained in a straightforward manner and their impact onto the 
photophysical properties of copper-halide species with different nuclearity in the solid state at both room and cryogenic temperature.

\section{Results and discussion}

\subsection{Synthesis of the phosphine ligands P1-P4}

Phosphines P1-P4 were synthesized in one-step procedure starting from diphenylphosphine, namely $\mathrm{Ph}_{2} \mathrm{PH}$, and the corresponding alkene derivative (i.e. methyl vinyl ketone, ethyl acrylate, tert-butyl acrylate, itaconic acid methyl ester), according to our previously reported procedure [51]: they were prepared by addition of the corresponding alkene compounds on $\mathrm{Ph}_{2} \mathrm{PH}$ (1.2 equiv.) in presence of 2-MeTHF (4 equiv.) under argon atmosphere in a closed vessel. The hydrophosphination product was then easily isolated by flash chromatography on silica with yield ranging from $81 \%$ to $95 \%$ (Table 1). The hydrophosphination of itaconic methyl ester generated a product that contains a chiral center, which was next used in its racemic form.

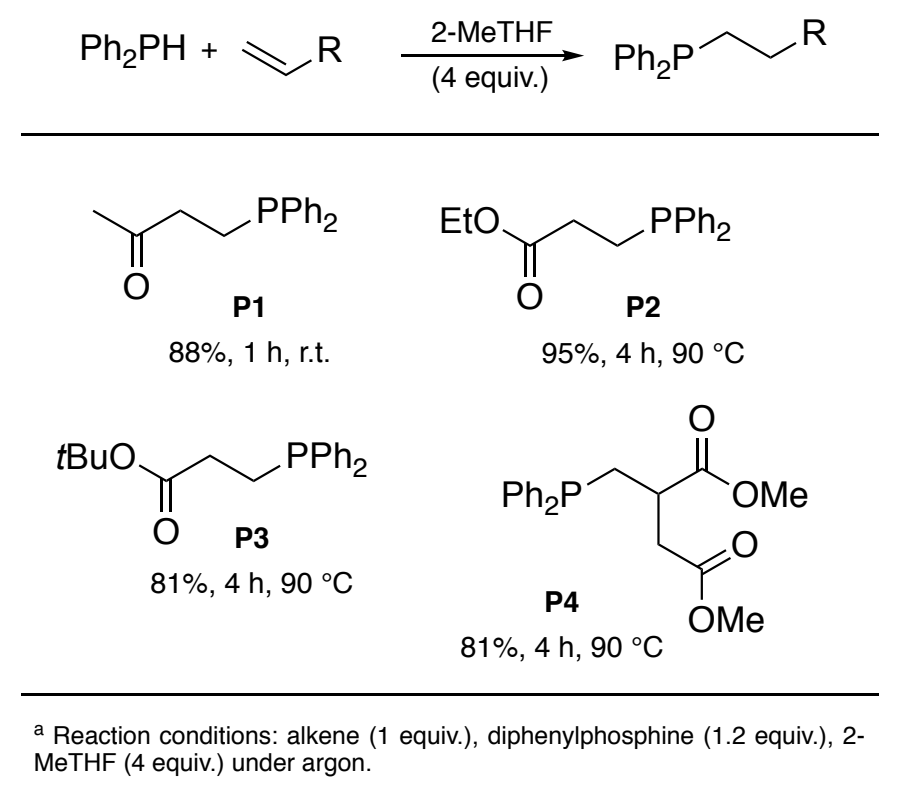

Table 1. Catalyst-free hydrophosphination of alkenes in the presence of 4 equiv. of 2MeTHF: synthesis of phosphine ligands P1-P4.

\subsection{Synthesis and crystal structure of the mononuclear copper complex $\mathbf{1}_{\mathbf{P 1 A}}$}


The monuclear copper(I) complex $\mathbf{1}_{\mathbf{P 1 A}}$ bearing phosphine ligand $\mathbf{P 1}$ and pyridine $\mathbf{A}$ was prepared in $85 \%$ yield by mechanochemical synthesis by mixing copper iodide $\mathrm{CuI}$ with two equivalents of the phosphine ligand in the presence of pyridine ( $c a .20$ equiv.) in a mortar (Scheme 1). The ligand/metal stoichiometry of the product was determined by elemental analyses and then confirmed by X-ray diffraction studies on single crystal obtained from $n$ hexane/dichloromethane. Figure 1 displays the molecular structure of the compound along with selected bond distances and angles. Complex $\mathbf{1}_{\mathbf{P 1 A}}$ was crystallized in the space group $\mathrm{P} 2{ }_{1} / \mathrm{c}$. The complex adopts a mononuclear tetrahedral coordination geometry. An edge-to-face $\mathrm{CH}-\pi$ intramolecular interaction between the two phosphine ligands was noted [distance of $2.85 \AA$ between the hydrogen $\mathrm{H}(24)$ and $\mathrm{C}(7)]$. The torsion angle between the pyridine and the $\mathrm{Cu}-\mathrm{I}$ bond is of ca. $9^{\circ}[\mathrm{C}(37)-\mathrm{N}(1)-\mathrm{Cu}(1)-\mathrm{I}(1)]$.
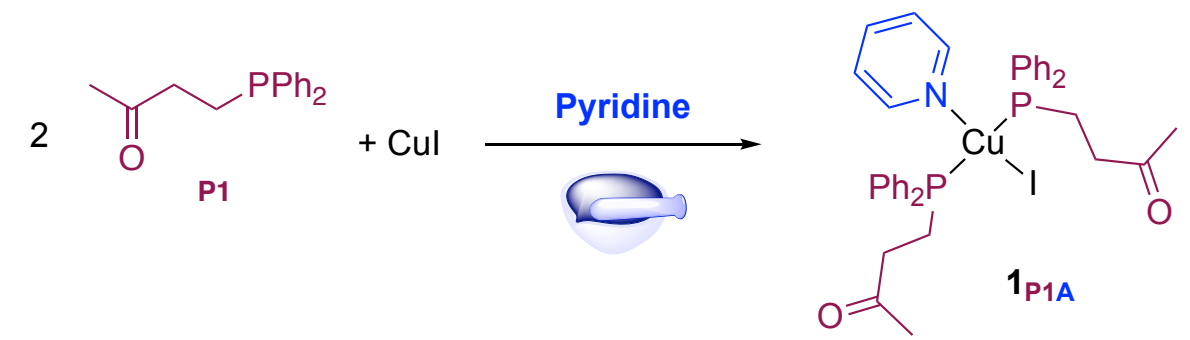

Scheme 1. Synthesis of the mononuclear complex $\mathbf{1}_{\mathbf{P 1 A}}$ of formula $\left[\mathrm{CuI}(\right.$ pyridine $\left.)(\mathbf{P 1})_{2}\right]$ by grinding procedure. 


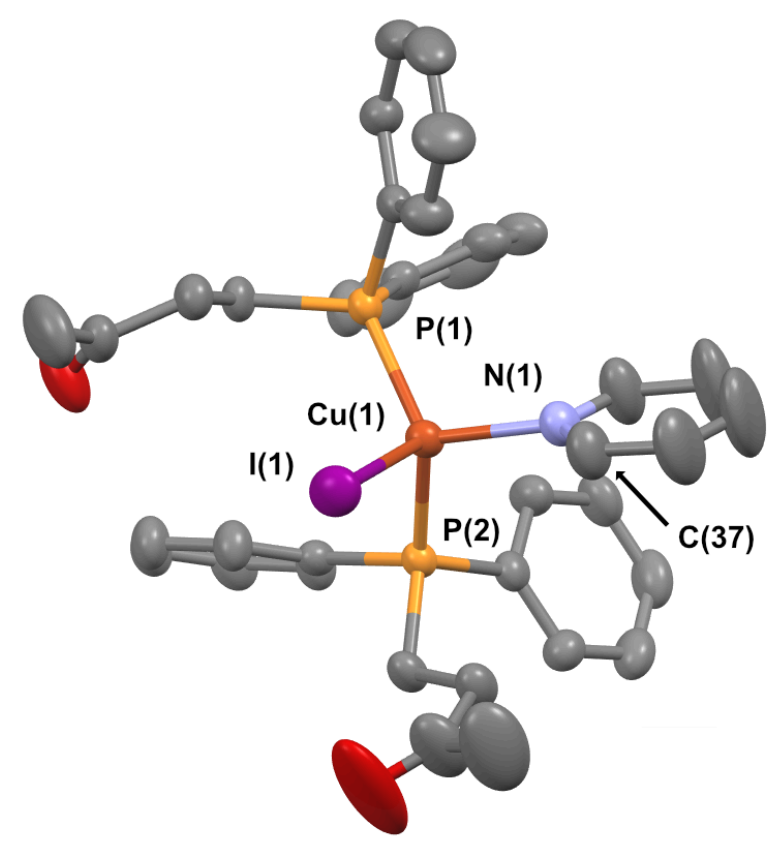

Figure 1. Single-crystal X-ray molecular structure of copper complex 1P1A. Selected bond distances $(\AA)$ and angles $\left({ }^{\circ}\right)$ : $\mathrm{Cu}(1)-\mathrm{N}(1), 2.080(2) ; \mathrm{Cu}(1)-\mathrm{P}(1), 2.2534(7) ; \mathrm{Cu}(1)-\mathrm{P}(2)$, 2.2588(7); $\mathrm{Cu}(1)-\mathrm{I}(1), 2.6438(4) ; \mathrm{N}(1)-\mathrm{Cu}(1)-\mathrm{P}(1), 112.55(6) ; \mathrm{N}(1)-\mathrm{Cu}(1)-\mathrm{P}(2), 108.18(6)$; $\mathrm{N}(1)-\mathrm{Cu}(1)-\mathrm{I}(1), 103.89(6) ; \mathrm{P}(1)-\mathrm{Cu}(1)-\mathrm{P}(2), 115.74(2) ; \mathrm{P}(1)-\mathrm{Cu}(1)-\mathrm{I}(1), \quad 109.824(19) ;$ $\mathrm{P}(2)-\mathrm{Cu}(1)-\mathrm{I}(1), 105.811(19) ; \mathrm{C}(37)-\mathrm{N}(1)-\mathrm{Cu}(1)-\mathrm{I}(1), 9.04(4)$.

\subsection{Synthesis of the iodo-bridged binuclear copper complexes $\boldsymbol{2}_{P I A}, \boldsymbol{2}_{P I B}$ and $\mathbf{2}_{P I C}$}

The dinuclear copper(I) complexes bearing phosphine ligand P1 were prepared by mechanochemical synthesis by mixing stoichiometrically $\mathrm{CuI}$ and $\mathbf{P} \mathbf{1}$ in presence of nitrogenbased ligand pyridine A (20 equiv.), quinoline B (1 equiv.) or 4-cyanopyridine $\mathbf{C}$ (1 equiv.), giving complexes $\mathbf{2}_{\mathbf{P 1 A}}, \mathbf{2}_{\mathbf{P 1 B}}$ and $\mathbf{2}_{\mathbf{P 1 C}}$, respectively (74-76\% yield). All compounds were characterized by ${ }^{1} \mathrm{H},{ }^{13} \mathrm{C},{ }^{31} \mathrm{P}$ NMR and elemental analysis and the data are reported in the experimental section and supporting information. Crystals of $\mathbf{2}_{\mathbf{P 1 A}}$ suitable for X-ray analysis were obtained from $n$-hexane/dichloromethane (Figure 2). Complex $\mathbf{2}_{\mathbf{P 1 A}}$ was crystallized in the triclinic space group P-1. The copper exhibits a tetrahedral coordination with P-Cu-N angle of $118.75(5)^{\circ}$. The $\mathrm{Cu}_{2} \mathrm{I}_{2}$ geometry is perfectly planar $\left[\mathrm{Cu}(1)-\mathrm{I}(1)-\mathrm{Cu}\left(1^{\prime}\right)-\mathrm{I}\left(1^{\prime}\right)=0.00\right]$ with a $\mathrm{Cu}(1)-\mathrm{I}(1)$ distance of $2.65 \AA$ and $\mathrm{Cu}(1)-\mathrm{I}\left(1^{\prime}\right)$ of $2.71 \AA$. The $\mathrm{Cu}{ }^{\cdots} \mathrm{Cu}$ distance is $3.0566 \AA$ indicating no interaction between the two copper atoms as compared with sum of 
the van der Waals radius of copper $(2.8 \AA)$. The pendant and flexible ketone arm of the phosphine ligands is pointing inside the cavity presents on both side of the $\mathrm{Cu}_{2} \mathrm{I}_{2}$ square and the ketone function is placed almost parallel to the adjacent pyridine ligand $[\mathrm{C}(21)-\mathrm{N}(1)-$ $\mathrm{C}\left(3^{\prime}\right)-\mathrm{O}\left(1^{\prime}\right)=2 \cdot 3^{\circ}$. Crystals of complex $\mathbf{2}_{\mathbf{P 1 C}}$ were also obtained and used for X-ray analysis (Figure 3). The dinuclear complex $\mathbf{2}_{\mathbf{P 1 C}}$ has a molecular arrangement identical to the previous complex albeit with a shorter $\mathrm{Cu} \cdots \mathrm{Cu}$ distance $(2.8769 \AA)$.
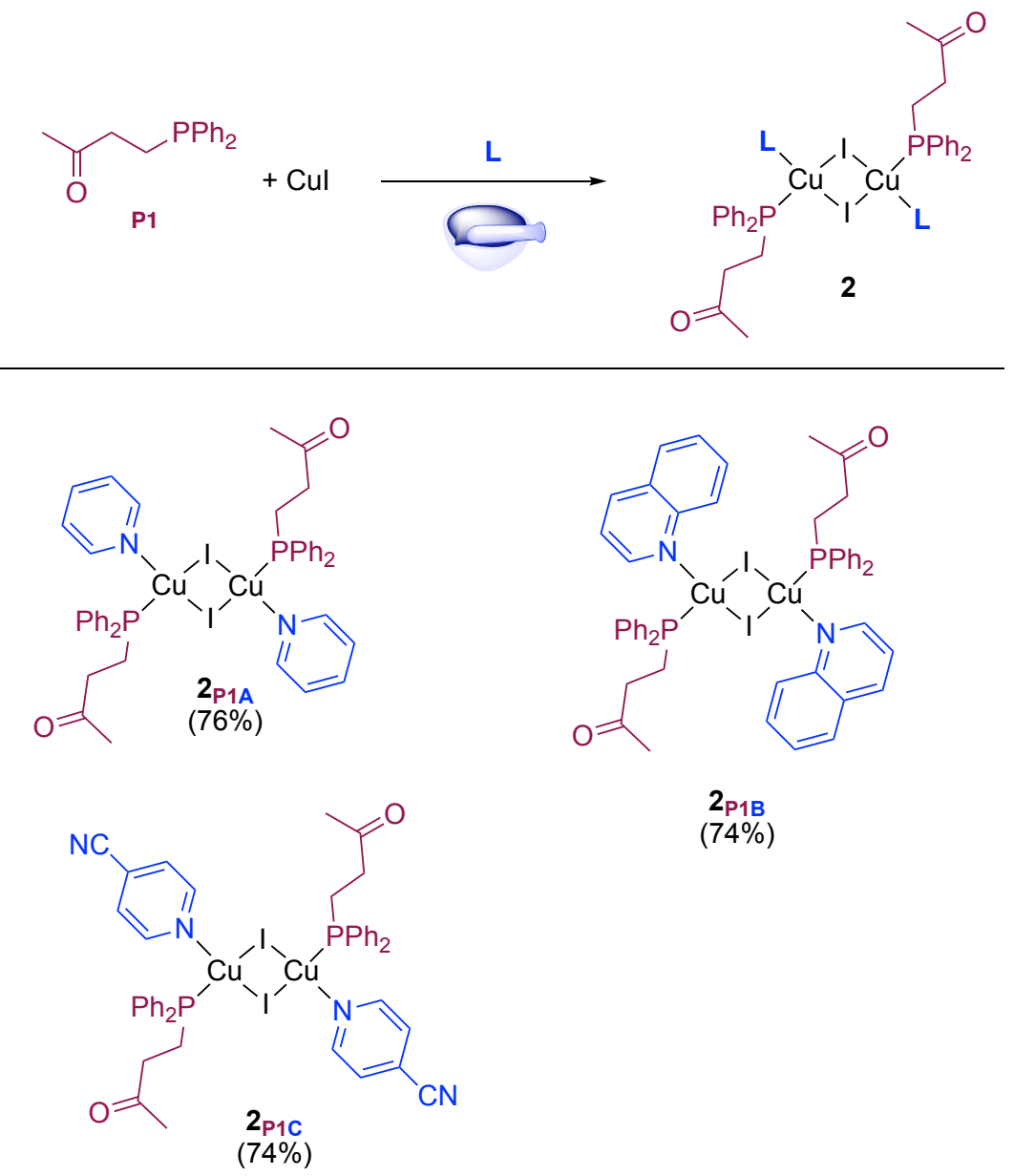

$\mathbf{2}_{\mathrm{P} 1 \mathrm{~B}}$

$(74 \%)$

Scheme 2. Synthesis of binuclear copper(I) complexes of formula $[\mathrm{Cu}(\mu-\mathrm{X})(\mathrm{L})(\mathbf{P 1})]_{2}$ by grinding, where $\mathrm{L}=$ pyridine $\left(\mathbf{2}_{\mathbf{P 1 A}}\right)$, quinoline $\left(\mathbf{2}_{\mathbf{P 1 B}}\right)$ and 4 -cyanopyridine $\left(\mathbf{2}_{\mathbf{P 1 C}}\right)$. 


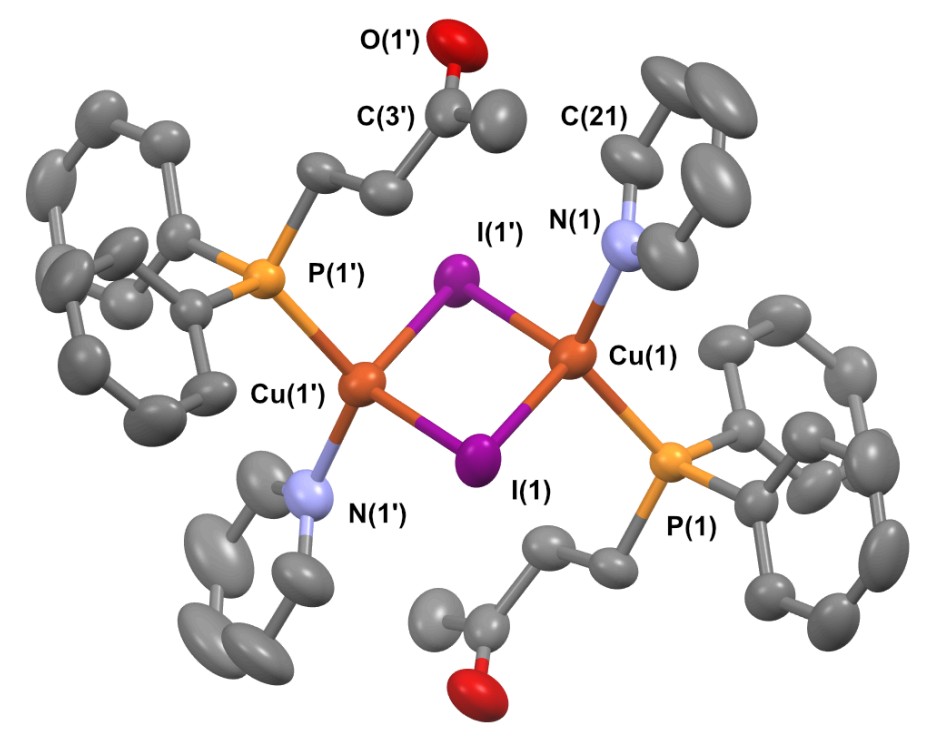

Figure 2. Single-crystal X-ray molecular structure of copper complex 2p1A. Selected bond distances $(\AA)$ and angles (deg): $\mathrm{Cu}(1)-\mathrm{N}(1), 2.0600(17) ; \mathrm{Cu}(1)-\mathrm{P}(1), 2.2311(5) ; \mathrm{Cu}(1)-\mathrm{I}(1)$, 2.7124(3); $\mathrm{Cu}(1)-\mathrm{I}\left(1^{\prime}\right), 2.6533(3) ; \mathrm{Cu}(1)-\mathrm{Cu}\left(1^{\prime}\right), 3.0566(5) ; \mathrm{N}(1)-\mathrm{Cu}(1)-\mathrm{P}(1), 118.75(5)$; $\mathrm{N}(1)-\mathrm{Cu}(1)-\mathrm{I}(1), 106.01(5) ; \quad \mathrm{N}(1)-\mathrm{Cu}(1)-\mathrm{I}\left(1^{\prime}\right), 104.45(6) ; \mathrm{P}(1)-\mathrm{Cu}(1)-\mathrm{I}(1), 101.059(15) ;$ $\mathrm{P}(1)-\mathrm{Cu}(1)-\mathrm{I}\left(1^{\prime}\right), 115.587(16) ; \mathrm{I}(1)-\mathrm{Cu}(1)-\mathrm{I}\left(1^{\prime}\right), 110.558(9) ; \mathrm{Cu}(1)-\mathrm{I}(1)-\mathrm{Cu}\left(1^{\prime}\right), 69.442(9)$; $\mathrm{Cu}(1)-\mathrm{I}(1)-\mathrm{Cu}\left(1^{\prime}\right)-\mathrm{I}\left(1^{\prime}\right), 0.00(4)$.

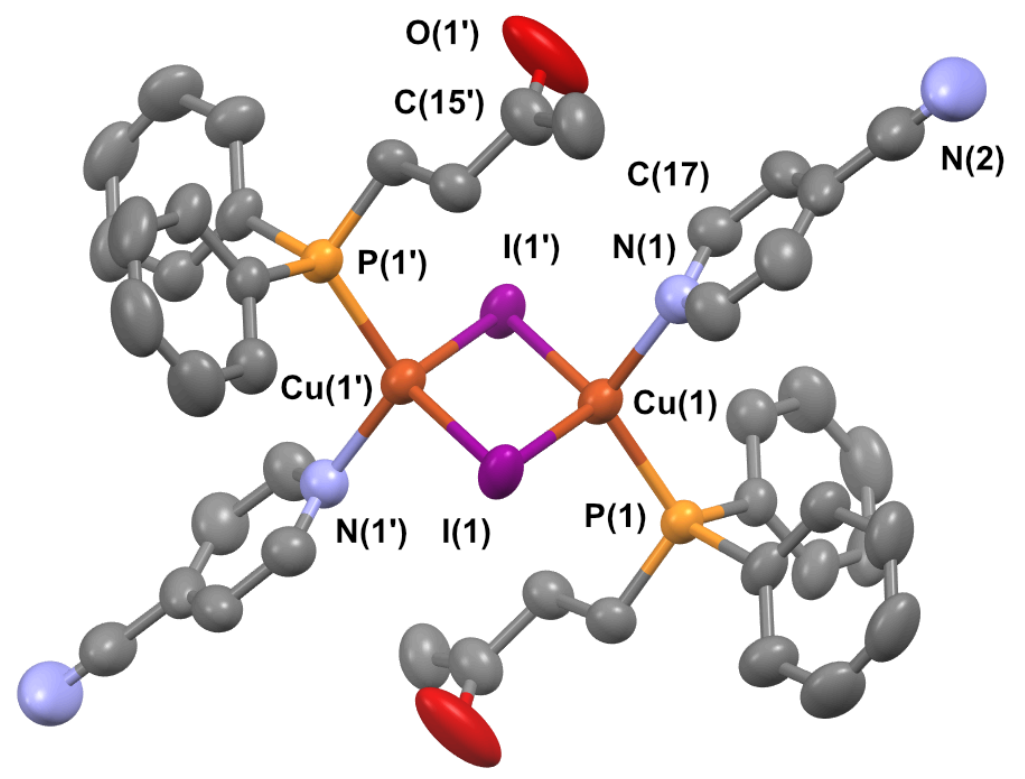

Figure 3. Single-crystal X-ray molecular structure of copper complex 2P1C. Selected bond distances $(\AA)$ and angles (deg): $\mathrm{Cu}(1)-\mathrm{N}(1), 2.068(4) ; \mathrm{Cu}(1)-\mathrm{P}(1), 2.2366(11) ; \mathrm{Cu}(1)-\mathrm{I}(1)$, 2.6446(5); $\mathrm{Cu}(1)-\mathrm{I}\left(1^{\prime}\right), 2.6854(6) ; \mathrm{Cu}(1)-\mathrm{Cu}\left(1^{\prime}\right), 2.8769(9) ; \mathrm{N}(1)-\mathrm{Cu}(1)-\mathrm{P}(1), 114.02(10)$; $\mathrm{N}(1)-\mathrm{Cu}(1)-\mathrm{I}(1), 103.67(10) ; \mathrm{P}(1)-\mathrm{Cu}(1)-\mathrm{I}(1), 116.04(3) ; \mathrm{P}(1)-\mathrm{Cu}(1)-\mathrm{I}\left(1^{\prime}\right), 103.89(3) ; \mathrm{I}(1)-$ $\mathrm{Cu}(1)-\mathrm{I}\left(1^{\prime}\right), 114.671(18) ; \mathrm{Cu}(1)-\mathrm{I}(1)-\mathrm{Cu}\left(1^{\prime}\right), 65.329(17) ; \mathrm{Cu}(1)-\mathrm{I}(1)-\mathrm{Cu}\left(1^{\prime}\right)-\mathrm{I}\left(1^{\prime}\right), 0.00(3)$. 


\subsection{Synthesis of the binuclear copper complexes $\mathbf{2}_{\boldsymbol{P 2 A}}, \mathbf{2}_{\mathbf{P 3 A}}, \mathbf{2}_{\mathbf{P 4 A}}$}

The dinuclear copper (I) complexes $\mathbf{2}_{\mathbf{P 2 A}}, \mathbf{2}_{\mathbf{P 3 A}}$ and $\mathbf{2}_{\mathbf{P 4 A}}$ bearing phosphine ligands P2, P3 and P4 were prepared by mechanochemical synthesis by mixing stoichiometrically copper iodide and the phosphine in presence of 20 equiv. of pyridine $\mathbf{A}$ giving the product in yield ranging from $65 \%$ to $71 \%$. Among all attempts to get crystals, only $\mathrm{Cu}$ complex $\mathbf{2}_{\mathbf{P} 4 \mathrm{~A}}$ bearing the itaconic acid-based moiety gave crystals of sufficient quality for X-ray diffraction studies. Figure 4 displays the molecular structure along with selected bond lengths and angles. Complex 2 $24 \mathrm{~A}$ was crystallized in the triclinic $\mathrm{P}-1$ space group. The $\mathrm{Cu}_{2} \mathrm{I}_{2}$ geometry is planar and highly symmetric with a $\mathrm{Cu}(1)-\mathrm{I}(1)$ distance of $2.695 \AA$ and $\mathrm{Cu}(1)-\mathrm{I}\left(1^{\prime}\right)$ of $2.700 \AA$ and a $\mathrm{Cu} \cdots \mathrm{Cu}$ distance of $3.005 \AA$. The complex is a meso dimer thus consisting of a racemic mixture of ligand P4. In contrast with the previous structure, the ester functions point to the outside of the molecule, probably due to their bulk. 

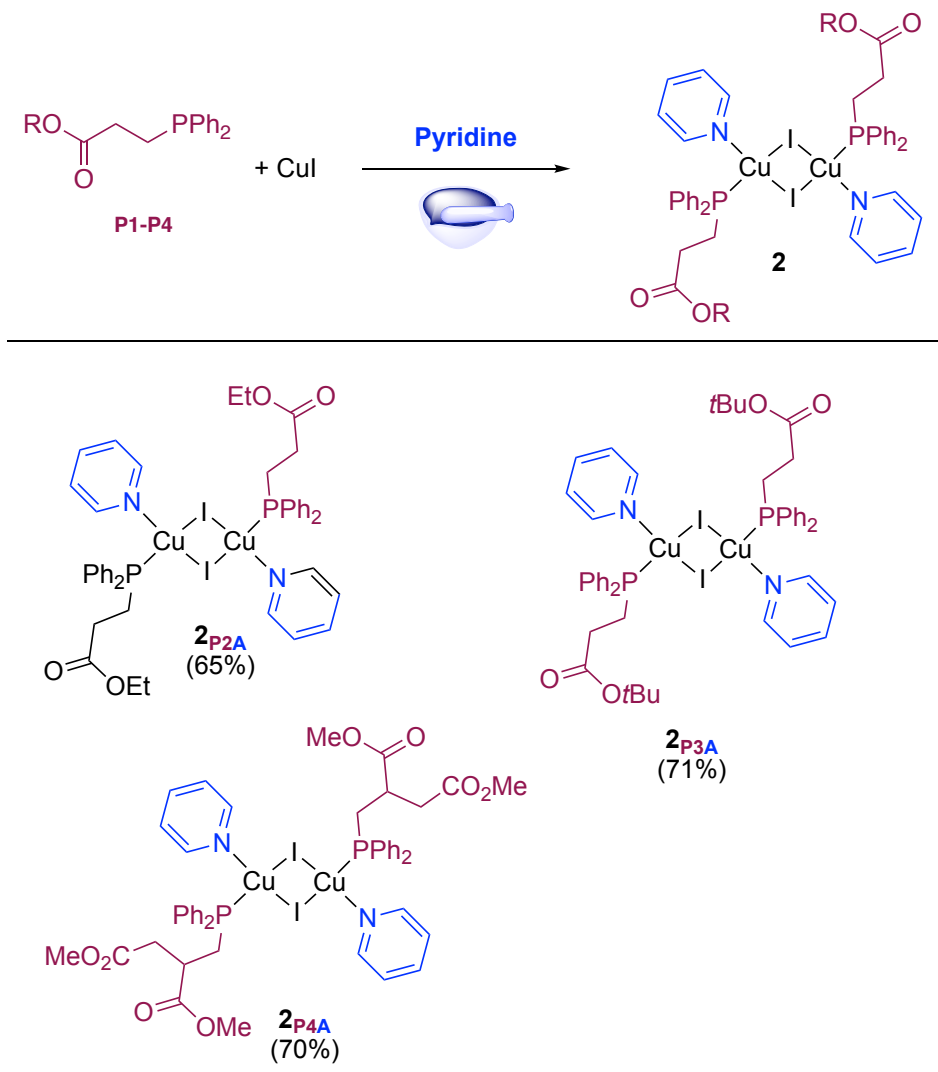

2P3A
$(71 \%)$

Scheme 3. Synthesis of pyridine binuclear copper(I) complexes with phosphines P2, P3 and P4.

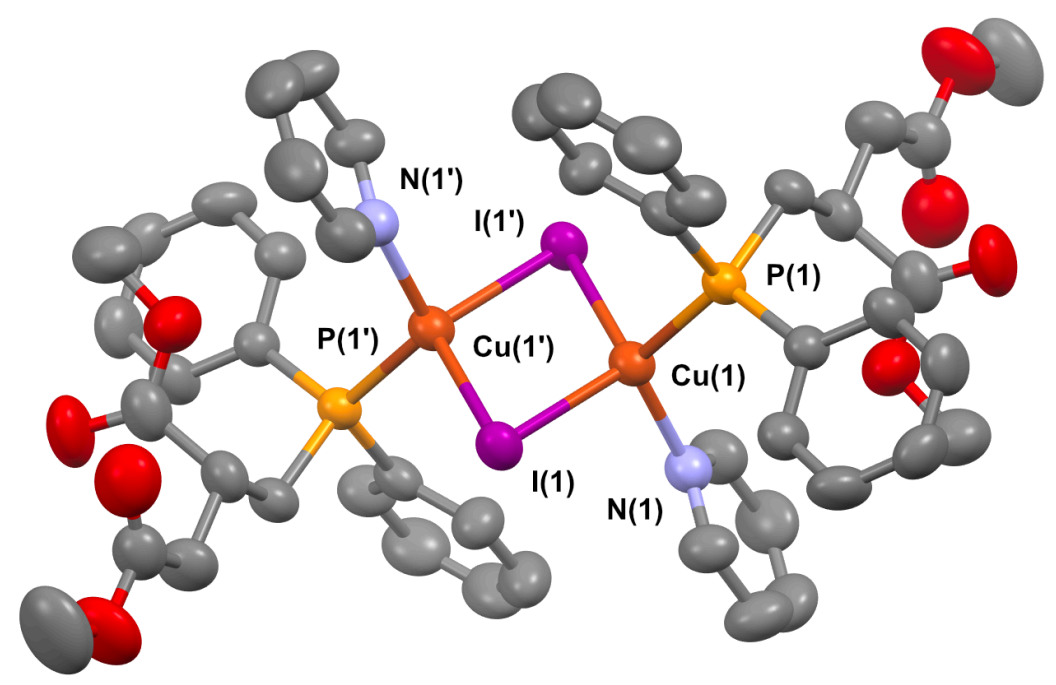

Figure 4. Single-crystal X-ray molecular structure of copper complex 2P4A. Selected bond distances $(\AA)$ and angles (deg): $\mathrm{Cu}(1)-\mathrm{N}(1), 2.0 .54(3)$; $\mathrm{Cu}(1)-\mathrm{P}(1), 2.2348(10) ; \mathrm{Cu}(1)-\mathrm{I}(1)$, 2.6953(5); $\mathrm{Cu}(1)-\mathrm{I}\left(1^{\prime}\right), 2.6997(5) ; \mathrm{Cu}(1)-\mathrm{Cu}\left(1^{\prime}\right)$, 3.0051(9); $\mathrm{N}(1)-\mathrm{Cu}(1)-\mathrm{P}(1), 117.93(10)$; $\mathrm{N}(1)-\mathrm{Cu}(1)-\mathrm{I}(1), 103.41(10) ; \mathrm{N}(1)-\mathrm{Cu}(1)-\mathrm{I}\left(1^{\prime}\right), 105.74(9) ; \mathrm{P}(1)-\mathrm{Cu}(1)-\mathrm{I}(1), 110.41(3) ; \mathrm{P}(1)-$ $\mathrm{Cu}(1)-\mathrm{I}\left(1^{\prime}\right), 107.08(3) ; \mathrm{I}(1)-\mathrm{Cu}(1)-\mathrm{I}\left(1^{\prime}\right), 112.300(17) ; \mathrm{Cu}(1)-\mathrm{I}(1)-\mathrm{Cu}\left(1^{\prime}\right), 67.700(17) ; \mathrm{Cu}(1)-$ $\mathrm{I}(1)-\mathrm{Cu}\left(1^{\prime}\right)-\mathrm{I}\left(1^{\prime}\right), 0.00(3)$. 


\subsection{Synthesis of the cubane-like copper cluster $\mathbf{3}_{\mathbf{P 1}}$}

Silica gel was found to be an excellent medium for the synthesis of cubane-type complex $\mathbf{3}_{\mathbf{P 1}}$ (Scheme 4). The tetranuclear complex was obtained in quantitative yield by passing solution of complex 2 2 P1A trough a silica gel column $\left(\mathrm{CH}_{2} \mathrm{Cl}_{2}\right.$ as solvent). Alternatively, complex $3_{\mathbf{P 1}}$ could be synthesized directly by mixing an equimolar amount of $\mathrm{CuI}$ with phosphine ligand 3a in toluene at $100^{\circ} \mathrm{C}$ for one day. Suitable crystals were obtained from dichloromethane/diethyl ether. Complex $3_{\mathbf{P} 1}$ was crystallized in the monoclinic $\mathrm{P} 2{ }_{1} / \mathrm{c}$ space group and has the general formula $\left[\mathrm{Cu}_{4} \mathrm{I}_{4} \mathrm{~L}_{4}\right]$ with L being P1 (Figure 5). In complex $\mathbf{3}_{\mathbf{P} 1}$, the $\mathrm{Cu}-\mathrm{I}$ bond distances and $\mathrm{I}-\mathrm{Cu}-\mathrm{I}$ angle values are within the range of reported values for such type of compound containing phosphorus-based ligands.[44,46] The copper cluster has a mean $\mathrm{Cu}^{\cdots} \mathrm{Cu}$ distance of $2.77 \AA$, which may imply weak cuprophilic interactions.
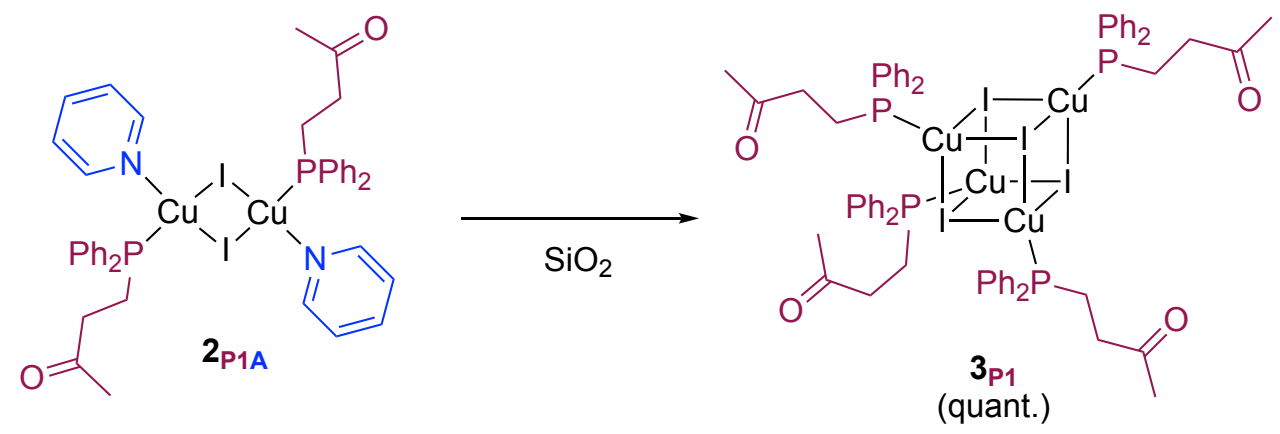

Scheme 4. Transformation of binuclear complex 21A $_{\text {P1A }}$ into copper cluster $3_{\text {P1 }}$ over silica. 


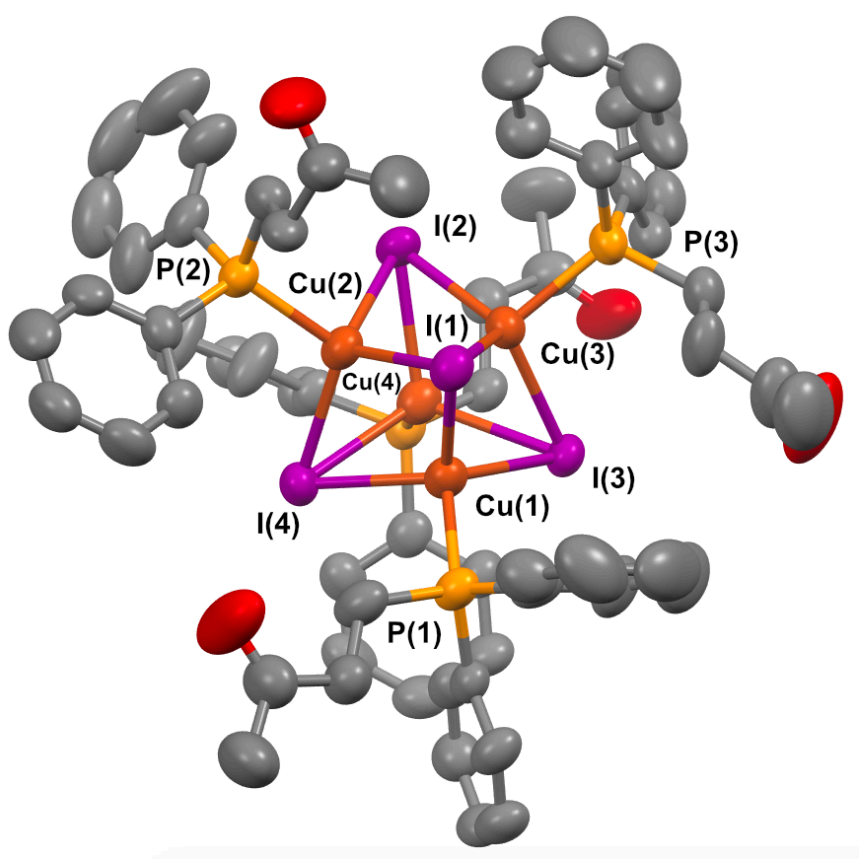

Figure 5. Single-crystal X-ray molecular structure of copper complex $\mathbf{3}_{\mathbf{P 1}}$. Selected bond distances $(\AA)$ and angles (deg): $\mathrm{Cu}(1)-\mathrm{P}(1), 2.2446(16) ; \mathrm{Cu}(1)-\mathrm{I}(1), 2.7369(8) ; \mathrm{Cu}(1)-\mathrm{I}(3)$, 2.6376(8); $\mathrm{Cu}(1)-\mathrm{I}(4), 2.7042(8) ; \mathrm{Cu}(1)-\mathrm{Cu}(2), 2.7893(10) ; \mathrm{Cu}(1)-\mathrm{Cu}(3), 2.7331(10) ; \mathrm{Cu}(1)-$ $\mathrm{Cu}(4), 2.7015(10) ; \quad \mathrm{Cu}(2)-\mathrm{P}(2), 2.2572(16) ; \mathrm{Cu}(2)-\mathrm{I}(2), 2.7108(8) ; \mathrm{Cu}(2)-\mathrm{I}(1), 2.7088(8) ;$ $\mathrm{Cu}(2)-\mathrm{I}(4), 2.6735(9), \quad \mathrm{Cu}(2)-\mathrm{Cu}(3), 2.8016(10) ; \mathrm{Cu}(2)-\mathrm{Cu}(4), 2.8835(10) ; \mathrm{Cu}(3)-\mathrm{P}(3)$, 2.2482(16); $\mathrm{Cu}(3)-\mathrm{I}(1), 2.6562(8) ; \mathrm{Cu}(3)-\mathrm{I}(2), 2.6723(8) ; \mathrm{Cu}(3)-\mathrm{I}(3), 2.7058(8) ; \mathrm{Cu}(3)-\mathrm{Cu}(4)$, 2.7359(10); $\mathrm{Cu}(4)-\mathrm{P}(4), 2.2473(16) ; \mathrm{Cu}(4)-\mathrm{I}(2), 2.6647(8) ; \mathrm{Cu}(4)-\mathrm{I}(3), 2.7039(8) ; \mathrm{Cu}(4)-\mathrm{I}(4)$, 2.7414(8); $\mathrm{P}(1)-\mathrm{Cu}(1)-\mathrm{I}(1), 98.82(5) ; \mathrm{P}(1)-\mathrm{Cu}(1)-\mathrm{I}(3), 113.60(5) ; \mathrm{P}(1)-\mathrm{Cu}(1)-\mathrm{I}(4), 105.04(5)$; $\mathrm{P}(1)-\mathrm{Cu}(1)-\mathrm{Cu}(2), 133.30(5) ; \mathrm{P}(1)-\mathrm{Cu}(1)-\mathrm{Cu}(3), 144.58(6) ; \mathrm{P}(1)-\mathrm{Cu}(1)-\mathrm{Cu}(4), 151.49$ (6).

\subsection{Photophysical characterization}

Fluid dilute samples in $\mathrm{CH}_{2} \mathrm{Cl}_{2}$ solution of the investigated complexes did not display any detectable photoluminescence. This is in line with previous investigation of related copperhalide species and it was ascribed to their chemical instability owing to flexible nature of the complex's scaffold and ligand dissociation. $[8,12,24-26]$ On the other hand, all the derivatives were brightly emissive in the solid state as neat powders at both room temperature and $77 \mathrm{~K}$ and the corresponding photophysical data are summarized in Table 2. All the neat powders resulted to be thermally- and photo-stable (see Figure S25-S32) microcrystalline samples. The powder X-ray pattern of all the solid-state samples was recorded and compared with the simulated one obtained from single-crystal structure (when available), confirming the similar 
nature structure of the two kinds of samples with the exception of samples of compound $\mathbf{2}_{\mathbf{P} 4 \mathbf{A}}$. The data are displayed in Figure S41-S46 of the supporting information.

Upon photoexcitation, compound 1P1A displays a broad and featureless emission spectrum with maximum centered at $\lambda_{\mathrm{em}}=470 \mathrm{~nm}$ with moderate intensity $(\mathrm{PLQY}=0.31$ ) that can be ascribed to an excited state with charge-transfer (CT) nature and shows a biexponential decay, being $\tau_{1}=25.1 \mu \mathrm{s}(78 \%), \tau_{2}=10.3 \mu \mathrm{s}(22 \%)$. Lowering the temperature down to $77 \mathrm{~K}$ induces a bathochromic shift of the emission profile of the powder samples with an emission maximum at $\lambda_{\mathrm{em}}=498 \mathrm{~nm}$, accompanied by sizeable prolongation of the excited state lifetime $(\tau=106.6 \mu \mathrm{s})$ and remarkable increase of the emission efficiency $(\mathrm{PLQY}=0.89)$. This latter can be mainly attributed to the one order of magnitude decrease of $k_{\mathrm{nr}}$ as consequence of the reduced molecular movements present at such cryogenic temperature. The emission spectra of $\mathbf{1}_{\mathbf{P 1 A}}$ are displayed in Figure 6 for both temperatures. 
Table 2. Photophysical data of all the copper-iodide derivatives herein investigated, recorded in the solid state as neat powders at room temperature and $77 \mathrm{~K}$. Excited state lifetimes were recorded upon excitation at $\lambda_{\mathrm{exc}}=375 \mathrm{~nm}$. PLQYs were recorded upon excitation at $\lambda_{\text {exc }}=$ $320 \mathrm{~nm}$.

\begin{tabular}{|c|c|c|c|c|c|c|c|c|c|c|}
\hline \multirow[b]{2}{*}{ Compound } & \multicolumn{5}{|c|}{ room temperature } & \multicolumn{5}{|c|}{$77 K$} \\
\hline & $\begin{array}{c}\lambda_{\mathrm{em}} \\
{[\mathrm{nm}]}\end{array}$ & PLQY & $\begin{array}{c}\bar{\tau}^{\mathrm{a}} \\
{[\mu \mathrm{s}]}\end{array}$ & $\begin{array}{c}k_{\mathrm{r}}^{b} \\
{\left[\times 10^{4} \mathrm{~s}^{-1}\right]}\end{array}$ & $\begin{array}{c}k_{\mathrm{nr}}{ }^{c} \\
{\left[\times 10^{4} \mathrm{~s}^{-1}\right]}\end{array}$ & $\begin{array}{c}\lambda_{\mathrm{em}} \\
{[\mathrm{nm}]}\end{array}$ & PLQY & $\begin{array}{c}\bar{\tau}^{\mathrm{a}} \\
{[\mu \mathrm{s}]}\end{array}$ & $\begin{array}{c}k_{\mathrm{r}}^{b} \\
{\left[\times 10^{4} \mathrm{~s}^{-1}\right]}\end{array}$ & $\begin{array}{c}k_{\mathrm{nr}}{ }^{c} \\
{\left[\times 10^{3} \mathrm{~s}^{-1}\right]}\end{array}$ \\
\hline 1P1A & 470 & 0.31 & 23.5 & 1.32 & 2.94 & 498 & 0.89 & 106.6 & 0.84 & 1.03 \\
\hline $2_{\mathrm{P} 1 \mathrm{~A}}$ & 485 & 0.42 & 20.5 & 2.05 & 2.83 & 495 & 0.85 & 89.0 & 0.96 & 1.69 \\
\hline $2_{\mathrm{P} 1 \mathrm{~B}}$ & 595 & 0.32 & 20.6 & 1.55 & 3.30 & 592 & 0.54 & 159.8 & 0.34 & 2.88 \\
\hline $2_{\mathrm{P} 1 \mathrm{C}}$ & 610 & 0.29 & 10.3 & 2.82 & 6.89 & 598 & 0.34 & 52.8 & 0.64 & 12.5 \\
\hline $2 \mathrm{P} 2 \mathrm{~A}$ & 445 & 0.40 & 11.3 & 3.54 & 5.31 & 448 & 0.97 & 25.7 & 3.77 & 1.17 \\
\hline $2 \mathrm{P3A}$ & 465 & 0.32 & 12.2 & 2.62 & 5.57 & 455 & 0.79 & 58.3 & 1.36 & 3.60 \\
\hline $2 \mathrm{P} 4 \mathrm{~A}$ & 475 & 0.50 & 13.6 & 3.68 & 3.68 & 475 & 0.85 & 74.7 & 1.14 & 2.01 \\
\hline $3_{\mathrm{P} 1}$ & $\begin{array}{c}425(\mathrm{HE}) \\
605(\mathrm{LE})\end{array}$ & 0.28 & $6.6^{d}$ & 4.24 & 10.9 & $\begin{array}{c}419(\mathrm{HE}) \\
593(\mathrm{LE})\end{array}$ & 0.67 & $3.9^{d}$ & 17.2 & 84.6 \\
\hline
\end{tabular}

${ }^{a}$ average lifetimes, $\bar{\tau}$, were calculated by using eqn. 2 (see experimental details); ${ }^{b} k_{\mathrm{r}}$ were estimated by using the $\bar{\tau}$ and the employing the following equation $k_{\mathrm{r}}=\mathrm{PLQY} / \bar{\tau}$; ${ }^{c} k_{n \mathrm{r}}$ were estimated by using the $\bar{\tau}$ and the employing the following equation $k_{\mathrm{nr}}=(1-\mathrm{PLQY}) / \bar{\tau} ;{ }^{d}$ measured at $\lambda_{\mathrm{em}}=605 \mathrm{~nm}$. HE $=$ high-energy band; LE $=$ low-energy band. 


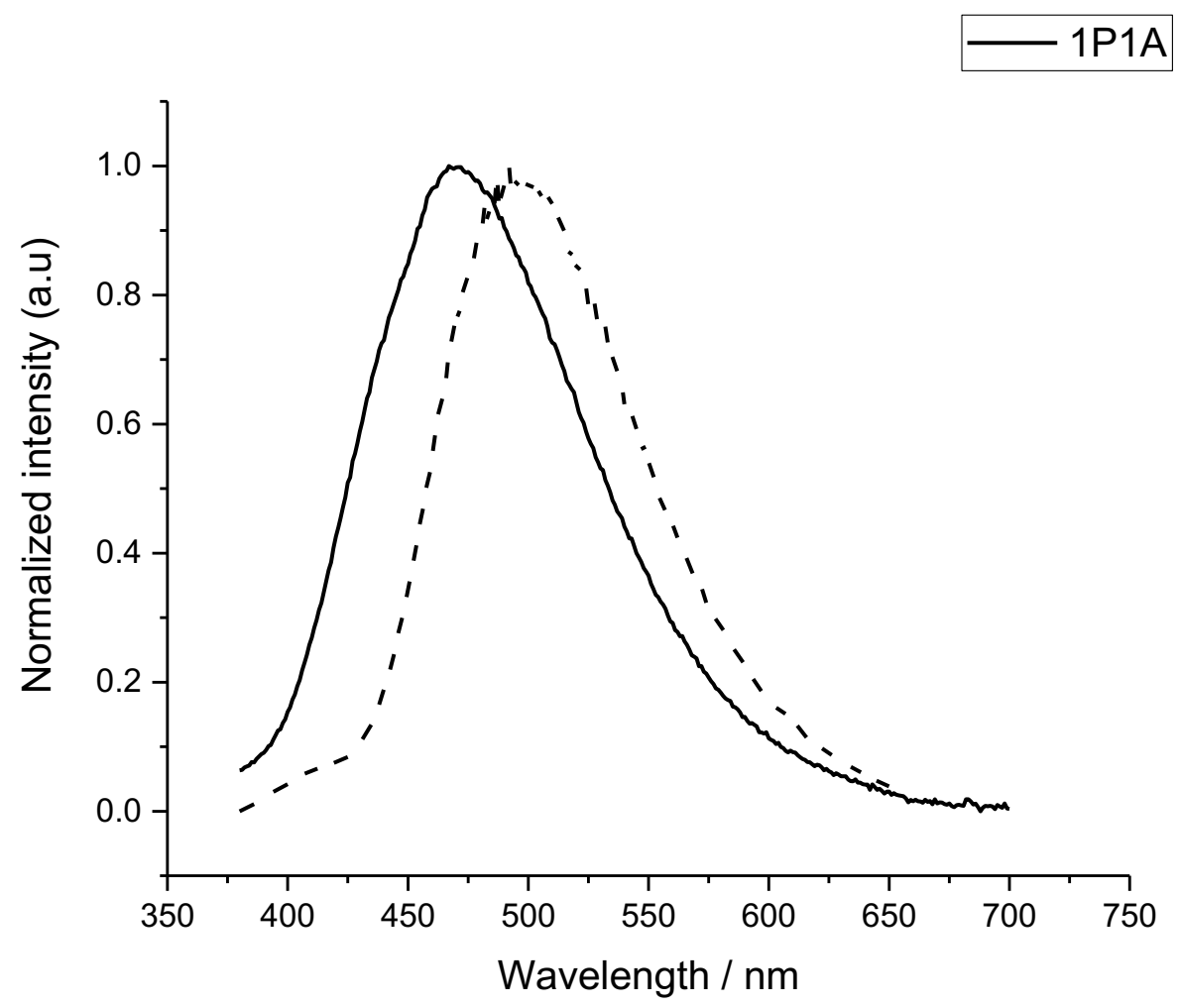

Figure 6. Emission spectra of compound $\mathbf{1}_{\mathbf{P 1 A}}$ as neat powder at room temperature and (solid trace) and $77 \mathrm{~K}$ (dashed trace) upon excitation at $\lambda_{\mathrm{exc}}=300 \mathrm{~nm}$.

Notably, the lowering of the temperature is further accompanied by a small decrease of the $k_{\mathrm{r}}$, from $1.32 \times 10^{4}$ to $8.4 \times 10^{3} \mathrm{~s}^{-1}$. On the basis of these findings one can thus assume that at low temperature the radiative process arises from an excited state with an almost pure triplet nature and admixed ${ }^{3}(\mathrm{M}+\mathrm{X}) \mathrm{LCT}$ character; whilst, a thermally-assisted equilibration between the lowest-lying ${ }^{3}(\mathrm{M}+\mathrm{X}) \mathrm{LCT}$ and the higher-lying ${ }^{1}(\mathrm{M}+\mathrm{X}) \mathrm{LCT}$ state seems to take place at room temperature and the observed emission could be tentatively ascribed to the delayed fluorescence arising from an emissive ${ }^{1}$ MLCT manifold. Thus, the spectral shift of ca. $1200 \mathrm{~cm}^{-1}(c a .0 .15 \mathrm{eV})$ provides an estimation of the energetic gap, namely $\Delta E_{\mathrm{S}-\mathrm{T}}$, between these two excited states.[52] Although a conclusive attribution of such phenomenon to TADF would require variable-temperature investigation of the excited state lifetime, it is 
worth to notice that these findings are in nice agreement with related derivatives of the same family reported previously.[9,24-26]

The photophysical properties of the investigated dinuclear complexes show rather striking differences within the series. The corresponding emission spectra are displayed in Figure 7.

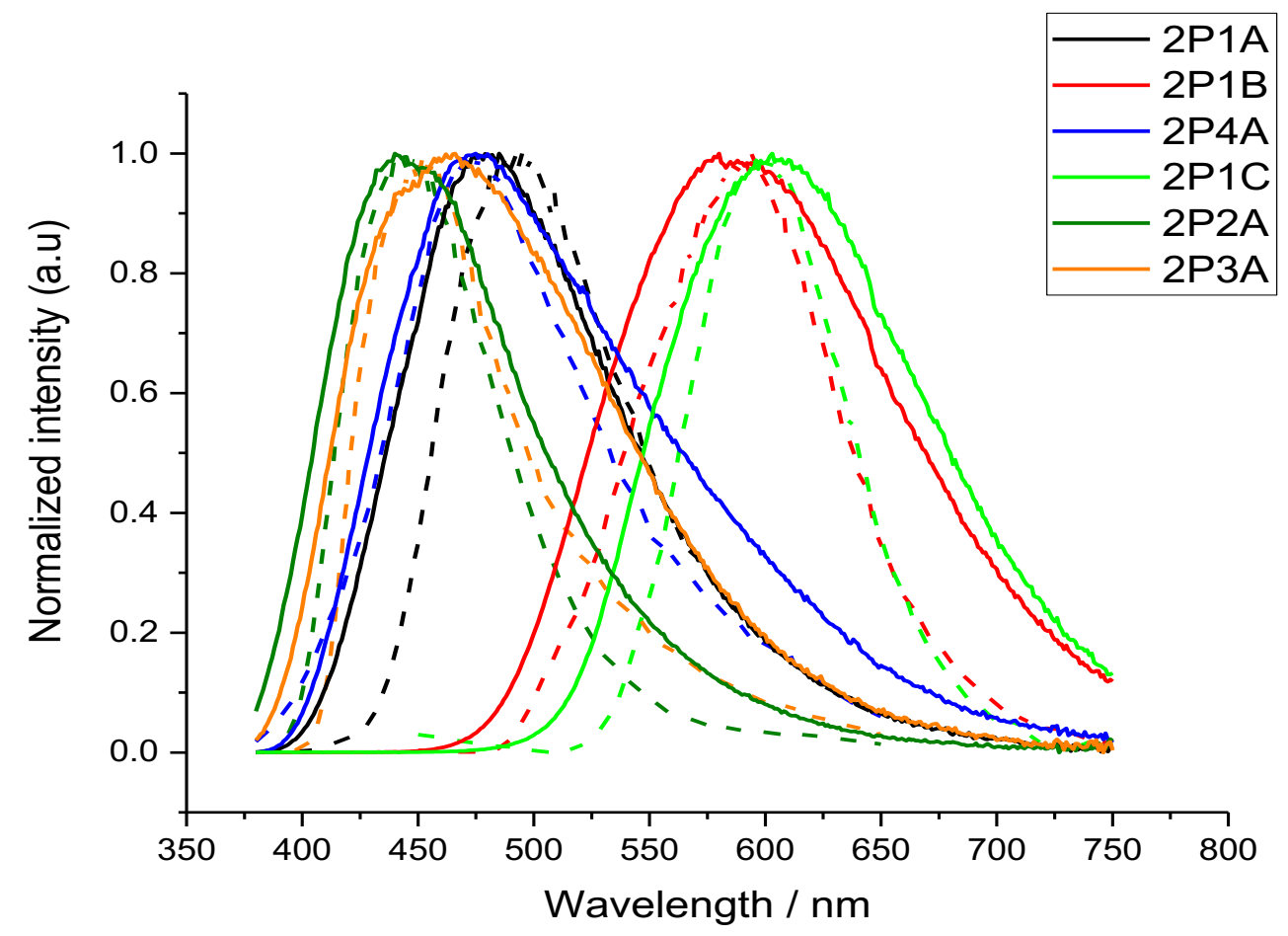

Figure 7. Emission spectra of compound $\mathbf{2}_{\mathbf{P 1 A}}$ (black trace), $\mathbf{2}_{\mathbf{P 1 B}}$ (red trace), $\mathbf{2}_{\mathrm{P} 1 \mathrm{C}}$ (light gree trace), $\mathbf{2}_{\mathbf{P 4 A}}$ (blue trace), $\mathbf{2}_{\mathbf{P 2 A}}$ (dark green trace) and $\mathbf{2}_{\mathbf{P 3 A}}$ (orange trace) as neat powder at room temperature and (solid traces) and $77 \mathrm{~K}$ (dashed traces) upon excitation at $\lambda_{\text {exc }}=300$ $\mathrm{nm}$.

Firstly, we examined compounds $\mathbf{2}_{\mathbf{P 1 A}}$ and compared its emission to that of $\left[\mathrm{CuI}\left(\mathrm{PPh}_{3}\right)(\mathrm{py})\right]_{2}$ congener reported previously. As far as the latter is concerned, slightly different data are available in the literature. In an earlier report, $\left[\mathrm{CuI}\left(\mathrm{PPh}_{3}\right)(\mathrm{py})\right]_{2}$ is described possessing an emission spectra with maximum at $\lambda_{\mathrm{em}}=444 \mathrm{~nm}$ at both $298 \mathrm{~K}$ and $77 \mathrm{~K}$ with a 
prolongation of the excited state lifetime upon lowering the temperature, being $\tau_{298 \mathrm{~K}}=11 \mu \mathrm{s}$ and $\tau_{77 \mathrm{~K}}=45 \mu \mathrm{s}$.[8] More recently, Sasaki [12] reported photoluminescence with an emission maximum at $\lambda_{\mathrm{em}}=500 \mathrm{~nm}$ with a bi-exponential decay $\left(\tau_{290 \mathrm{~K}}=22\right.$ and $\left.4.2 \mu \mathrm{s}\right)$ at $290 \mathrm{~K}$ ascribed to an excited state with ${ }^{3} \mathrm{CT}$ character with $\left\{\mathrm{Cu}_{2} \mathrm{X}_{2}\right\} \rightarrow \pi^{*}$ character. This assignment was as also corroborated by the hypsochromic shift to $\lambda_{\mathrm{em}}=450 \mathrm{~nm}\left(\tau_{80 \mathrm{~K}}=39\right.$ $\mu \mathrm{s})$ observed on cooling the sample down to $80 \mathrm{~K}$. Nonetheless, we observed a remarkably different emission behavior for complex 2 $\mathbf{P 1 A}$, which simply differs from $\left[\mathrm{CuI}\left(\mathrm{PPh}_{3}\right)(\text { py) }]_{2}\right.$ by the phosphine coordinated onto the $\left\{\mathrm{Cu}_{2} \mathrm{X}_{2}\right\}$. Indeed, $\mathbf{2}_{\mathbf{P 1 A}}$ displays an broad and featureless emission profile centered at $\lambda_{\mathrm{em}}=485 \mathrm{~nm}$ at room temperature with PLQY $=0.42$, which is bathochromically shifted compared to $\left[\mathrm{CuI}\left(\mathrm{PPh}_{3}\right)(\mathrm{py})\right]_{2}$ as consequence of the more electron donating nature of the phosphine P1, and with bi-exponential decay kinetics $\left[\tau_{1,298 \mathrm{~K}}=23.5 \mu \mathrm{s}\right.$ $(60 \%)$ and $\left.\tau_{2,298 \mathrm{~K}}=8.97 \mu \mathrm{s}(40 \%), \tau_{\mathrm{av}}=20.5 \mu \mathrm{s}\right]$. In sharp contrast, the bathochromic shift to $\lambda_{\mathrm{em}}=495 \mathrm{~nm}(\mathrm{PLQY}=0.96)$ and the much longer lifetime $\left(\tau{ }_{77 \mathrm{~K}}=89.0 \mu \mathrm{s}\right)$ observed at lower temperature along with the two-fold decrease of $k_{\text {r }}$ point towards the occurrence of a thermally-assisted delayed fluorescence process and support an emission arising from a thermally-equilibrated emissive ${ }^{1}(\mathrm{M}+\mathrm{X}) \mathrm{LCT}$ excited state at room temperature, lying higher in energy by $\Delta E_{\mathrm{S}-\mathrm{T}}=417 \mathrm{~cm}^{-1}$. This different behavior is mostly likely attributable to structural and packing effects imparted by the substituted phosphine $\mathbf{P 1}$ in the aggregated state. On the other hand, compound $\mathbf{2}_{\mathbf{P 1 B}}$ and $\mathbf{2}_{\mathbf{P 1 C}}$, which bear the same phosphine ligand 1a, but different $\pi$-accepting heteroaromatic ligands, namely quinoline $\mathbf{B}$ and 4-cyanopyridine $\mathbf{C}$, respectively, seem to do not show TADF features. Both complexes show a bathochromic shift of the emission with respect to complex $\mathbf{2}_{\mathbf{P 1 A}}$ due the more extended $\pi$-conjugation of the quinoline and 4-cyanopyridine when compared to the unsubstituted pyridine. Furthermore, while prolongation of the lifetime is observed upon cooling, the corresponding emission spectrum displays a small hypsochromic shift that can be attributed to the partial CT nature of 
the emissive state, along with a sharpening of the profile that owing to the rigidification of the molecular skeleton imposed by the lower temperature. Therefore, it is plausible that the $(\mathrm{M}+\mathrm{X}) \mathrm{CT}$ excited state admixes with the ${ }^{3} \pi-\pi^{*}$ state that lies at lower energy in $\mathbf{2}_{\mathbf{P} 1 \mathbf{B}}$ and $\mathbf{2}_{\mathbf{P 1 C}}$ owing to the more $\pi$-accepting ability of quinoline and 4-cyanopyridine ligands. These picture is in agreement with the conclusions drawn in a previous report on related derivatives and with the small $k_{\mathrm{r}}$ values observed at $77 \mathrm{~K}$ that underpin the main involvement of ${ }^{3} \pi-\pi^{*}$ states at low temperature.[12]

Secondly, we compare the photophysics of $\mathbf{2}_{\mathbf{P 1 A}}$ to the results obtained for $\mathbf{2}_{\mathbf{P 2 A}}, \mathbf{2}_{\mathbf{P} 3 \mathbf{A}}$, and $\mathbf{2}_{\mathbf{P 4 A}}$ which all contains pyridine as the $\pi$-accepting moiety, but different phosphine ligand, namely P1, P2, P3 and P4, respectively. The data are summarized in Table 2. It is reasonable to assume that the electron-donating property of the phosphines are rather similar, thus one might expect similar photoluminescence for the compounds in this series. Indeed, compound $\mathbf{2}_{\mathbf{P} 2 \mathrm{~A}}, \mathbf{2}_{\mathbf{P} 3 \mathbf{A}}$ and $\mathbf{2}_{\mathbf{P 4 A}}$ display a long-lived emission featuring a broad spectrum that is hypsochromically shifted by about $40 \mathrm{~nm}\left(1853 \mathrm{~cm}^{-1}\right), 20 \mathrm{~nm}\left(887 \mathrm{~cm}^{-1}\right)$ and $10 \mathrm{~nm}\left(434 \mathrm{~cm}^{-}\right.$ $\left.{ }^{1}\right)$ when compared to $\mathbf{2}_{\mathbf{P 1 A}}$ at room temperature with PLQY in the range $0.32-0.50$ and similar $k_{\mathrm{r}}$ values, indicating that the complexes share the same nature of the emitting excited state. Although, the more flexible nature of the phosphines in compounds $\mathbf{2}_{\mathbf{P 2 A}}, \mathbf{2}_{\mathbf{P 3 A}}$ and $\mathbf{2}_{\mathbf{P 4 A}}$ opens for more efficient radiationless deactivation channels as demonstrated by the increase of $k_{\mathrm{nr}}$ values. Lowering the temperature down to $77 \mathrm{~K}$ yields a prolongation of the excited state lifetimes, yet a minor effect onto the corresponding emission maximum is observed, with no clear evidence of TADF effect. Overall, it is evident that not only the electronic properties of the coordinated ligands onto the rhombic $\left\{\mathrm{Cu}_{2} \mathrm{X}_{2}\right\}$ scaffold, but also the solid-state environment can sizably influence the emissive properties of such class of compounds. Although the precise reason at the origin of such spectral shift observed for the series $\mathbf{2}_{\text {P1A }}$, $\mathbf{2}_{\mathbf{P} 2 \mathrm{~A}}, \mathbf{2}_{\mathbf{P} 3 \mathrm{~A}}$ and $\mathbf{2}_{\mathbf{P 4 A}}$, is not known at the current stage and further investigations are needed in 
this direction, these results clearly highlight the importance of the effects imparted by environment in changing the emission wavelength, colors purities and TADF processes; these are undoubtedly fundamental parameters in view of the potential applications of these compounds as solid state emitters. These factors might include the degree of crystallinity and crystalline phases, intermolecular interactions, constrain to the excited-state structural distortion imposed by the rigid environment, and defects acting as emission traps, to cite a few possibilities.[18,53,54-58]

Finally, the emission properties of the tetranuclear complex $\mathbf{3}_{\mathbf{P 1}}$ are evaluated and the spectra are displayed in Figure 8.

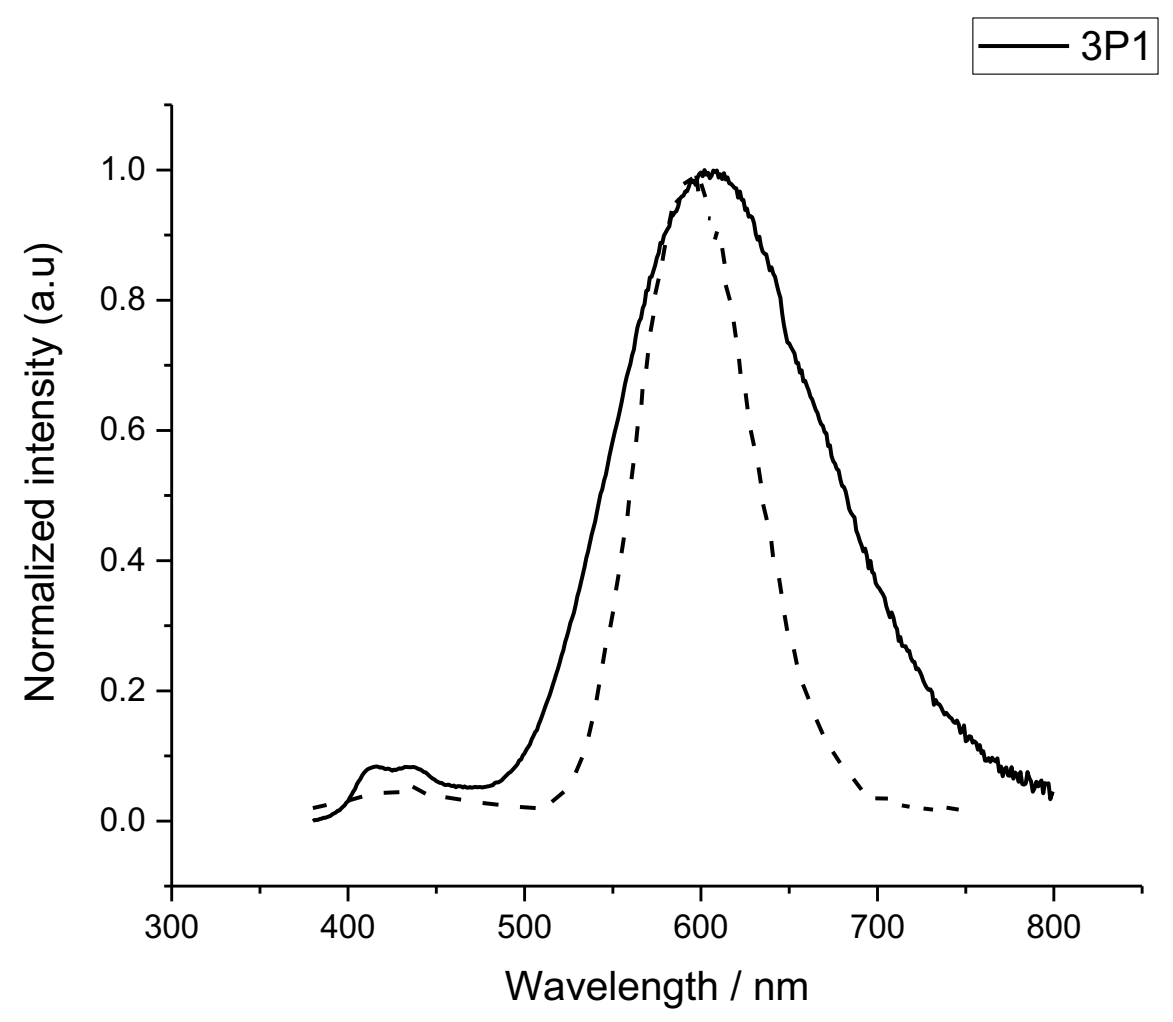

Figure 8. Emission spectra of compound $\mathbf{3}_{\mathrm{P} 1}$ as neat powder at room temperature and (solid trace) and $77 \mathrm{~K}$ (dashed trace) upon excitation at $\lambda_{\mathrm{exc}}=300 \mathrm{~nm}$.

At room temperature, the emission spectra of $\mathbf{3}_{\mathbf{P 1}}$ displays two bands, namely a high (HE) and a low energy (LE) band as typically of cubane-like copper clusters bearing N-heteroaromatic 
ligands $\left[\mathrm{Cu}_{4} \mathrm{I}_{4} \mathrm{~L}_{4}\right],[8,28,41]$ and phosphines $(\mathrm{P})\left[\mathrm{Cu}_{4} \mathrm{I}_{4} \mathrm{P}_{4}\right][44,46,47,59]$ with an overall PLQY of 0.32 . The two bands are centered at $\lambda_{\mathrm{em}}=425$ and $605 \mathrm{~nm}$ and are confidentially ascribed to two electronically-decoupled and thermally-equilibrated long-lived excited states with ${ }^{3} \mathrm{XLCT} /{ }^{3} \mathrm{MLCT}$ and ${ }^{3} \mathrm{CC} /{ }^{3} \mathrm{XLCT}$ nature (strong $\mathrm{Cu} 3 \mathrm{~d} \rightarrow 4 \mathrm{~s}, 4 \mathrm{p}$ character), respectively, on the basis of previous investigation on related species. Analysis of the excited state decay at the LE band results in a bi-exponential kinetics $\left(\tau_{\mathrm{av}}=6.6 \mu \mathrm{s}\right)$, although no risetime was observed; a value that could be comparable or shorter than the instrumental resolution employed. Interestingly, the maximum of the HE band nicely agree with the value reported for closelyrelated $\left[\mathrm{Cu}_{4} \mathrm{I}_{4}\left(\mathrm{PPh}_{2} \mathrm{Pr}\right)_{4}\right]$ derivative, where $\mathrm{PPh}_{2} \mathrm{Pr}$ is diphenylpropylphosphine [46]. It is worth to notice that owing to its nature, the LE band is instead sizably influenced by the extent of metal-metal interaction and distance.[8,28,42-42,45-46,49] As discussed above, compound $3_{\mathrm{P} 1}$ features an average $\mathrm{Cu} \cdots \mathrm{Cu}$ bond distance of $2.77 \AA$, a value that is shorter than the sum of the van der Waals radii for $\mathrm{Cu}(\mathrm{I}) 2.8 \AA$ [60] and amongst the shortest found for phosphine-capped cubane-like $\left\{\mathrm{Cu}_{4} \mathrm{I}_{4}\right\}$ structures,[47] thus highlighting the establishment of cuprophilic interactions between two adjacent iodo-bridged $\mathrm{d}^{10}$ metal centers. In consequence, the LE band for compound $\mathbf{3}_{\mathrm{P} 1}$ is bathochromically shifted when compared with other $[\mathrm{CuIP}]_{4}$ congeners that typically show emission in the region $\lambda_{\mathrm{em}}=520-580 \mathrm{~nm} \cdot[45-$ 46,49] Upon lowering the temperature down to $77 \mathrm{~K}$, the LE band still results in the predominant emission feature and only a small hypsochromic shift is observed to $\lambda_{\mathrm{em}}=593$ $\mathrm{nm}$ with concomitant narrower profile, most likely caused by the temperature induced geometrical distortion of the flexible $\left\{\mathrm{Cu}_{4} \mathrm{I}_{4}\right\}$ framework that reduces the metal-metal interaction at low temperature, thus destabilizing the emissive ${ }^{3} \mathrm{CC} /{ }^{3} \mathrm{XLCT}$ state [44]. The absence of neat thermochromism in the temperature window under investigation and, thus, the lack of increase of the relative intensity of the HE band compared to the LE one at lower temperature compared to other $\left[\mathrm{Cu}_{4} \mathrm{I}_{4} \mathrm{P}_{4}\right]$ species might be attributable to a smaller energetic 
barrier between the two states, ${ }^{3} \mathrm{XLCT} /{ }^{3} \mathrm{MLCT}$ and ${ }^{3} \mathrm{CC} /{ }^{3} \mathrm{XLCT}$, under thermal equilibrium. In turn, a fast and efficient population of this latter state may occur even at $77 \mathrm{~K}$, which can still emit efficiently $(\mathrm{PLQY}=0.67)$.

\section{Conclusion}

A series of eight novel luminescent copper(I) iodide complexes has been synthesized in good yields by mechanochemistry using easily accessible functionalized diphenylphosphino-type ligands. Full characterization including X-ray crystallographic studies for five of them and elemental analyses revealed their nuclearity. These compounds displayed no detectable photoluminescence in solution, however they were brightly emissive in the solid state as powders at both room temperature and low temperature $(77 \mathrm{~K})$. Among all investigated derivatives, two of them displayed photophysical features that may underpin TADF processes. In spite of the remote location of the functionalization of the phosphine ligands, noticeable effects were observed onto the solid-state emission properties thus highlighting the importance of microenvironment for the $\mathrm{Cu}(\mathrm{I})$-halide emitters in the aggregated phase in view of their potential application as active materials is solid-state light-emitting devices.

\section{Acknowledgments}

Financial support for this project was provided by the Région Grand Est (France) and Clariant (Muttenz, Switzerland). Dr. Lydia Brelot and Corinne Bailly are gratefully acknowledged for X-ray crystallographic analyses. Prof. Cristian A. Strassert, M. E. Gutierrez Suburu and I. Maisuls (Westfälische Wilhelms-Universitët Münster) are gratefully acknowledged for the help with the PLQY measurements.

\section{Experimental section}




\section{General comments}

All manipulations were carried under an air atmosphere (except for mechanosyntheses). Reagents were purchased from commercial chemical suppliers and used without further purification. Solvents were dried according to standard procedures. ${ }^{1} \mathrm{H},{ }^{13} \mathrm{C}\left\{{ }^{1} \mathrm{H}\right\}$ and ${ }^{31} \mathrm{P}\left\{{ }^{1} \mathrm{H}\right\}$ nuclear magnetic resonance (NMR) spectra were recorded on a Bruker Avance 300 spectrometer aor Bruker Avance III HD - $500 \mathrm{MHz} .{ }^{13} \mathrm{C}$ assignments were confirmed when necessary with the use of DEPT 135 experiments. ${ }^{1} \mathrm{H}$ and ${ }^{13} \mathrm{C}-\mathrm{NMR}$ spectra were referenced using the residual solvent peak $\left(\mathrm{CDCl}_{3}: \delta \mathrm{H}=7.26 \mathrm{ppm} ; \delta \mathrm{C}=77.16 \mathrm{ppm}\right)$ at $295 \mathrm{~K}$. Chemical shifts are reported in ppm $(\delta)$ compared to TMS $\left({ }^{1} \mathrm{H}\right.$ and $\left.{ }^{13} \mathrm{C}\right)$ using the residual peak of deuterated solvent as internal standard. MS spectra were performed by the mass spectrometry service of the "Institut de Chimie de Strasbourg" on microTOF, Bruker Daltonics. Elemental analyses were performed by the 'Service d'analyse élémentaire' of the Faculté de Chimie of the University of Strasbourg. For all the investigated complexes, the corresponding ${ }^{1} \mathrm{H},{ }^{13} \mathrm{C}$ and ${ }^{31} \mathrm{P}$ NMR spectra are displayed in Figure $\mathrm{S} 1-\mathrm{S} 24$ and the thermogravimetric analyses are shown in Figure S25-S32 of the Supporting Information.

\section{$X$-ray analyses}

Single crystal X-ray diffraction. For complexes $\mathbf{2}_{\mathbf{P 1 C}}, \mathbf{2}_{\mathrm{P2A}}$ and $\mathbf{5}$, X-ray diffraction data collection was carried out on a Nonius Kappa-CCD diffractometer equipped with an Oxford Cryosystem liquid $\mathrm{N}_{2}$ device, using Mo-K $\alpha$ radiation $(\lambda=0.71073 \AA)$. The crystal-detector distance was $36 \mathrm{~mm}$. The cell parameters were determined (Denzo software)[61] from reflections taken from one set of 10 frames $\left(1.0^{\circ}\right.$ steps in phi angle), each at 20 seconds exposure. The structures were solved by direct methods using the program SHELXS2013.[62] The refinement and all further calculations were carried out using SHELXL2013.[63] The H-atoms were included in calculated positions and treated as riding atoms 
using SHELXL default parameters. The non-H atoms were refined anisotropically, using weighted full-matrix least-squares on $F^{2}$. A semi-empirical absorption correction was applied using the MULscanABS routine in PLATON.[64]

For complexes 1P1A and 2P1A, X-ray diffraction data collection was carried out on a Bruker APEX II DUO Kappa-CCD diffractometer equipped with an Oxford Cryosystem liquid $\mathrm{N}_{2}$ device, using Mo-K $\alpha$ radiation $(\lambda=0.71073 \AA)$. The crystal-detector distance was $38 \mathrm{~mm}$. The cell parameters were determined (APEX2 software)[65] from reflections taken from tree sets of 12 frames, each at 10 seconds exposure. The structure was solved by direct methods using the program SHELXS-97.[66] The refinement and all further calculations were carried out using SHELXL-97. The H-atoms were included in calculated positions and treated as riding atoms using SHELXL default parameters. The non-H atoms were refined anisotropically, using weighted full-matrix least-squares on $F^{2}$. A semi-empirical absorption correction was applied using SADABS in APEX2.

CCDC Deposition Numbers 2007757-2007761.

Powder X-ray diffractometic analyses. The powder XRD patterns were obtained with a transmission Guinier-like geometry. A linear focalized monochromatic $\mathrm{Cu} \mathrm{K}_{\alpha 1}$ beam $(\lambda=$ $1.5405 \AA$ ) was obtained using a sealed-tube generator $(600 \mathrm{~W})$ equipped with a bent quartz monochromator. The samples were filled in home-made sealed cells of adjustable path. The patterns were recorded on image plates and scanned by Amersham Typhoon IP with $25 \mu \mathrm{m}$ resolution. The intensity vs 2 theta profiles were obtained from images by using homedeveloped software.

The comparison between the simulated (when available from single-crystal structure) and experimental power diffraction patterns for the investigated copper complexes are displayed in Figure S41-S46 of the Supporting Information. 


\section{Synthetic procedures}

\section{General procedure for grinding method}

In a mortar, copper iodide and pyridine or nitrogen-containing derivative (x equivalents) were grinded together during 5 minutes. A yellow solution appeared directly after the addition of pyridine derivative. The adequate phosphine (one equivalent or two equivalents) was then added to the solution and the mixture was grinded during 10 minutes. The yellow mixture became colorless during the processing. Then dichloromethane was added and the solution was poured into $\mathrm{Et}_{2} \mathrm{O}$. The complex precipitated directly, was filtrated and washed several times with $\mathrm{Et}_{2} \mathrm{O}$. The product was dried under vacuum to afford the copper product.

\section{Synthesis of complex 1 $\mathbf{P 1 A}$}

Copper(I) iodide (75 mg, 0,390 mmol, 1 equiv.) was reacted with phosphine 1a (200 mg, $0.780 \mathrm{mmol}, 2$ equiv. $)$ and pyridine $(0.63 \mathrm{~mL}, 7.80 \mathrm{mmol}, 20$ equiv. $)$ according to the general procedure to give a white solid (186 mg, yield 85\%). Suitable crystals for X-Ray analysis were obtained by slow diffusion of vapor of $n$-hexane into a solution of complex in dichloromethane. ${ }^{1} \mathbf{H}$ NMR $\left(500 \mathrm{MHz}, \mathrm{CDCl}_{3}\right): \delta 8.63\left(\mathrm{br}, 2 \mathrm{H}, \mathrm{C} H_{\text {pyr }}\right), 7.68\left(\mathrm{t}, 1 \mathrm{H}, \mathrm{CH}_{\mathrm{pyr}}, J=\right.$ $7 \mathrm{~Hz}), 7.45-7.20\left(\mathrm{~m}, 12 \mathrm{H}, \mathrm{C} H_{\mathrm{ph}}\right), 7.26\left(\mathrm{~m}, 2 \mathrm{H}, \mathrm{C} H_{\mathrm{pyr}}\right), 7.24-7.19\left(\mathrm{~m}, 8 \mathrm{H} \mathrm{CH} H_{\mathrm{ph}}\right), 2.60(\mathrm{br}, 4 \mathrm{H}$, $\left.\mathrm{CH}_{2}-\mathrm{O}\right), 2.43$ (br, 4H, CH$\left.H_{2}-\mathrm{P}\right), 2.00\left(\mathrm{~s}, 6 \mathrm{H}, \mathrm{CH}_{3}\right)$ ppm. ${ }^{13} \mathbf{C}\left\{{ }^{1} \mathbf{H}\right\}$ NMR $\left(125 \mathrm{MHz}, \mathrm{CDCl}_{3}\right) \delta$ : 207.1; 149.6; 136.3; 133.4; 132.9 (d); 129.7: 128,58 (d); 123.9; 38.6 (d); 29.83; 21.69 (d) ppm. ${ }^{31} \mathbf{P}\left\{{ }^{1} \mathbf{H}\right\}$ NMR $\left(202 \mathrm{MHz}, \mathrm{CDCl}_{3}\right) \delta:-15.5$ (br) ppm. Anal. Calcd for $\mathrm{C}_{37} \mathrm{H}_{39} \mathrm{CuINO}_{2} \mathrm{P}_{2}: \mathrm{C}$, 56.82; H, 5.03; N, 1,79. Found: C, 56.56; H, 4.91; N, 1.27.

\section{Synthesis of complex $\mathbf{2}_{\mathbf{P 1 A}}$}


Copper(I) iodide (148 mg, $0.780 \mathrm{mmol}, 1 \mathrm{eq})$ was reacted with phosphine 1a (200 mg, 0.780 mmol, 1 eq.) and pyridine (1.25 mL, $15.6 \mathrm{mmol}, 20$ eq.) according to the general procedure previously mentioned to give a white solid (310 mg, yield 76\%). Suitable crystals for X-ray analysis were obtained by slow diffusion of vapor of $n$-hexane into a solution of complex in dichloromethane. ${ }^{1} \mathbf{H}$ NMR (500 MHz, $\left.\mathrm{CDCl}_{3}\right): \delta 8.66\left(\mathrm{~d}, 4 \mathrm{H}, \mathrm{CH}_{\mathrm{pyr}}, J=4 \mathrm{~Hz}\right), 7.67(\mathrm{tt}, 2 \mathrm{H}$, $\left.\mathrm{CH}_{\text {pyr }}, J=8 \mathrm{~Hz} ; 2 \mathrm{~Hz}\right), 7.57-7.48\left(\mathrm{~m}, 8 \mathrm{H}, \mathrm{CH}_{\mathrm{ph}}\right), 7.30\left(\mathrm{~m}, 4 \mathrm{H}, \mathrm{CH}_{\mathrm{pyr}}\right), 7.28-7.20(\mathrm{~m}, 12 \mathrm{H}$ $\left.\mathrm{CH}_{\mathrm{ph}}\right), 2.64$ (m, 4H, $\left.\mathrm{CH}_{2}-\mathrm{O}\right), 2.45\left(\mathrm{~m}, 4 \mathrm{H}, \mathrm{CH}_{2}-\mathrm{P}\right), 1.93$ (s, 6H, $\left.\mathrm{CH}_{3}\right)$ ppm. ${ }^{13} \mathbf{C}$ NMR (125 $\left.\mathrm{MHz}, \mathrm{CDCl}_{3}\right): \delta 207.40,150.26,136.63,133.40,133.02$ (d); 129.74, 128.53 (d), 124.12, 38.76 (d), 29.78, 21.33(d) ppm. ${ }^{31} \mathbf{P}\left\{{ }^{1} \mathbf{H}\right\}$ NMR (202 MHz, $\left.\mathrm{CDCl}_{3}\right): \delta-17.8$ (br) ppm. Anal. Calcd for $\mathrm{C}_{42} \mathrm{H}_{44} \mathrm{Cu}_{2} \mathrm{I}_{2} \mathrm{~N}_{2} \mathrm{O}_{2} \mathrm{P}_{2}$ : C, 47.97; H, 4.22; N, 2.66. Found: C, 47.50; H, 4.16; N, 2.40 .

\section{Synthesis of complex $\mathbf{2} \mathbf{P 1 \mathbf { B }}$}

Copper(I) iodide (148 mg, $0.780 \mathrm{mmol}, 1$ equiv.) was reacted with phosphine 1a $(200 \mathrm{mg}$, $0.780 \mathrm{mmol}, 1$ equiv.) and quinoline $(0.092 \mathrm{~mL}, 0.780 \mathrm{mmol}, 1$ equiv. $)$ according to the general procedure previously mentioned to give an orange solid (332 mg, yield $74 \%$ ). ${ }^{1} \mathbf{H}$ NMR (500 MHz, $\left.\mathrm{CDCl}_{3}\right): \delta 9.01\left(\mathrm{~d}, 2 \mathrm{H}, \mathrm{CH}_{\text {quino }}, J=4 \mathrm{~Hz}\right), 8.28\left(\mathrm{~d}, 2 \mathrm{H}, \mathrm{CH}_{\text {quino }}, J=7 \mathrm{~Hz}\right)$, $8.18\left(\mathrm{~d}, 2 \mathrm{H}, \mathrm{CH}_{\text {quino }}, J=8 \mathrm{~Hz}\right), 7.82\left(\mathrm{~d}, 2 \mathrm{H}, \mathrm{CH}_{\text {quino }}, J=8 \mathrm{~Hz}\right), 7.69$ (m, 2H, $\left.\mathrm{CH}_{\text {quino }}\right), 7.62-$ $7.53\left(\mathrm{~m}, 10 \mathrm{H} \mathrm{CH} \mathrm{ph}_{\mathrm{ph}}+\mathrm{CH}_{\text {quino }}\right), 7.40\left(\mathrm{dd}, 2 \mathrm{H}, \mathrm{CH}_{\text {quino }} J=4 \mathrm{~Hz}, 8 \mathrm{~Hz}\right), 7.35\left(\mathrm{~m}, 4 \mathrm{H}, \mathrm{CH}_{\mathrm{ph}}\right)$, 7.30-7.27 (m, 8H, $\mathrm{CH}_{\mathrm{ph}}$ ), 2.67 (m, 4H, $\left.\mathrm{CH}_{2}-\mathrm{O}\right), 2.50$ (m, 4H, $\left.\mathrm{CH}_{2}-\mathrm{P}\right), 1.94$ (s, 6H, $\left.\mathrm{CH}_{3}\right)$ ppm. ${ }^{13}$ C NMR (125 MHz, $\left.\mathrm{CDCl}_{3}\right): \delta 207.51,151.11,148.07,136.72,133.3$ (d, J=13 Hz), 133.06, 129.96, 129.82, 129.65, 128.69 (d, $J=8 \mathrm{~Hz}) ; 128.00,126.92,121.32,38.90(\mathrm{~d}, J=7 \mathrm{~Hz})$, 30.02, $21.17(\mathrm{~d}, J=21 \mathrm{~Hz}) \mathrm{ppm} .{ }^{31} \mathbf{P}\left\{{ }^{1} \mathbf{H}\right\} \mathbf{N M R}\left(202 \mathrm{MHz}, \mathrm{CDCl}_{3}\right): \delta-24,04$ (br) ppm. Anal. Calcd for $\mathrm{C}_{50} \mathrm{H}_{48} \mathrm{Cu}_{2} \mathrm{I}_{2} \mathrm{~N}_{2} \mathrm{O}_{2} \mathrm{P}_{2}: \mathrm{C}, 52.14 ; \mathrm{H}, 4.20 ; \mathrm{N}, 2.43$. Found: C, 51.97; H, 4.14; N, 2.38 .

Synthesis of complex $\mathbf{2}_{\mathbf{P 1 C}}$ 
Copper(I) iodide (37 mg, $0.195 \mathrm{mmol}, 1$ equiv.) was reacted with phosphine 1a (50 mg, 0.195 mmol, 1 equiv.) and 4-cyanopyridine (20 mg, $0.195 \mathrm{mmol}, 1$ equiv.) according to the general procedure previously mentioned to give an orange solid (332 mg, yield 74\%). Suitable crystals for X-Ray analysis were obtained by slow diffusion of vapor of hexane into a solution of complex in dichloromethane. ${ }^{1} \mathbf{H}$ NMR $\left(500 \mathrm{MHz}, \mathrm{CDCl}_{3}\right): \delta 8.81\left(\mathrm{~d}, 4 \mathrm{H}, \mathrm{CH}_{\text {pyr }}, J=4 \mathrm{~Hz}\right)$, 7.57-7.48 (m, 8H, $\left.\mathrm{CH}_{\mathrm{ph}}\right), 7.30\left(\mathrm{~m}, 4 \mathrm{H}, \mathrm{CH}_{\mathrm{pyr}}\right), 7.28-7.20\left(\mathrm{~m}, 12 \mathrm{H} \mathrm{CH}_{\mathrm{ph}}\right), 2.64\left(\mathrm{~m}, 4 \mathrm{H}, \mathrm{CH}_{2}-\right.$ O), 2,45 (m, 4H, $\left.\mathrm{CH}_{2}-\mathrm{P}\right), 1,94\left(\mathrm{~s}, 6 \mathrm{H}, \mathrm{CH}_{3}\right) \mathrm{ppm} .{ }^{13} \mathbf{C} \mathbf{N M R}\left(125 \mathrm{MHz}, \mathrm{CDCl}_{3}\right): \delta 207.33$, 151.00, 133.17 (d, $J=13 \mathrm{~Hz}), 132.79,129.82,128.53$ (d, $J=9 \mathrm{~Hz}), 125.54,120.68,116.23$, $38.67(\mathrm{~d}, J=7 \mathrm{~Hz}), 29.82,20.99(\mathrm{~d}, J=20 \mathrm{~Hz}) \mathrm{ppm} .{ }^{31} \mathbf{P}\left\{{ }^{1} \mathbf{H}\right\} \mathbf{N M R}\left(202 \mathrm{MHz}, \mathrm{CDCl}_{3}\right): \delta-$ 24.03 (br) ppm. Anal. Calcd for $\mathrm{C}_{44} \mathrm{H}_{42} \mathrm{Cu}_{2} \mathrm{I}_{2} \mathrm{~N}_{4} \mathrm{O}_{2} \mathrm{P}_{2}$ : C, 47.97; H, 3.84; N, 5.09. Found: C, 47.76; H, 3.65; N, 4.99.

\section{Synthesis of complex $\mathbf{2}_{\mathbf{P 2 A}}$}

Copper(I) iodide (199 mg, $1.05 \mathrm{mmol}, 1$ equiv.) was reacted with phosphine $\mathbf{1 b}$ (300 mg, 1.05 mmol, 1 equiv.) and pyridine (1.69 mL, $21 \mathrm{mmol}, 20$ equiv.) according to the general procedure previously mentioned to give a white solid (378 mg, yield 65\%). ${ }^{1} \mathbf{H}$ NMR (500 $\left.\mathrm{MHz}, \mathrm{CDCl}_{3}\right): \delta 8.66\left(\mathrm{~d}, 4 \mathrm{H}, \mathrm{CH}_{\mathrm{pyr}}, J=4 \mathrm{~Hz}\right), 7.65\left(\mathrm{tt}, 2 \mathrm{H}, \mathrm{CH}_{\mathrm{pyr}}, J=8 \mathrm{~Hz} ; 2 \mathrm{~Hz}\right), 7.57-7.48$ (m, 8H, $\mathrm{CH}_{\mathrm{ph}}$ ), $7.31\left(\mathrm{~m}, 4 \mathrm{H}, \mathrm{CH}_{\mathrm{pyr}}\right), 7.28-7.20\left(\mathrm{~m}, 12 \mathrm{H} \mathrm{CH}_{\mathrm{ph}}\right), 3.99$ (q, 4H, $\left.\mathrm{CH}_{2}, J=7 \mathrm{~Hz}\right)$, $2.50\left(\mathrm{~m}, 8 \mathrm{H}, \mathrm{CH}_{2}-\mathrm{O}\right.$ and $\left.\mathrm{CH}_{2}-\mathrm{P}\right), 1.14\left(\mathrm{t}, 6 \mathrm{H}, \mathrm{CH}_{3}, J=7 \mathrm{~Hz}\right)$ ppm. ${ }^{13} \mathbf{C}$ NMR $(125 \mathrm{MHz}$, $\left.\mathrm{CDCl}_{3}\right): \delta 172.91(\mathrm{~d}), 150.39,136.48,133.18(\mathrm{~d}), 132.86,129.71,128.54$ (d), 124.07, 60.59, 29.54 (d), 22.72(d), 14.20 ppm. ${ }^{31} \mathbf{P}\left\{{ }^{1} \mathbf{H}\right\}$ NMR (202 MHz, $\left.\mathrm{CDCl}_{3}\right): \delta-17.82$ (br) ppm. Anal. Calcd. for $\mathrm{C}_{44} \mathrm{H}_{48} \mathrm{Cu}_{2} \mathrm{I}_{2} \mathrm{~N}_{2} \mathrm{O}_{4} \mathrm{P}_{2}$ : C, 47.54; H, 4.35; N, 2.52. Found: C, 47.39; H, 4.45; N, 2.45. Synthesis of complex $\mathbf{2}_{\mathbf{P 3 A}}$

Copper(I) iodide (191 mg, $1.01 \mathrm{mmol}, 1$ equiv.) was reacted with phosphine 1c (300 mg, 1.01 mmol, 1 equiv.) and pyridine (1.62 mL, $20.1 \mathrm{mmol}, 20$ equiv.) according to the general 
procedure previously mentioned to give a white solid (412 mg, yield 71\%). ${ }^{1} \mathbf{H}$ NMR (500 $\left.\mathrm{MHz}, \mathrm{CDCl}_{3}\right): \delta 8.68\left(\mathrm{~d}, 4 \mathrm{H}, \mathrm{CH}_{\mathrm{pyr}}, J=4 \mathrm{~Hz}\right), 7.66\left(\mathrm{tt}, 2 \mathrm{H}, \mathrm{CH}_{\mathrm{pyr}}, J=8 \mathrm{~Hz} ; 2 \mathrm{~Hz}\right), 7.57-7.48$ (m, 8H, $\left.\mathrm{CH}_{\mathrm{ph}}\right), 7.31\left(\mathrm{~m}, 4 \mathrm{H}, \mathrm{CH}_{\mathrm{pyr}}\right), 7.28-7.20\left(\mathrm{~m}, 12 \mathrm{H} \mathrm{CH}_{\mathrm{ph}}\right), 2.50\left(\mathrm{~m}, 4 \mathrm{H}, \mathrm{CH}_{2}-\mathrm{O}\right), 2.40(\mathrm{~m}$, 4H, $\left.\mathrm{CH}_{2}-\mathrm{P}\right), 1.35\left(\mathrm{~s}, 18 \mathrm{H}, \mathrm{CH}_{3}\right)$ ppm. ${ }^{13} \mathbf{C}$ NMR (125 MHz, $\left.\mathrm{CDCl}_{3}\right): \delta 172.91(\mathrm{~d}, J=19 \mathrm{~Hz})$; 150.40, 136.50, 133.17 (d, $J=13 \mathrm{~Hz}), 133.00,129.67,128.54(\mathrm{~d}, J=8 \mathrm{~Hz}) ; 124.08,80.55$, $30.59(\mathrm{~d}, J=8 \mathrm{~Hz}), 28.12,22.68(\mathrm{~d}, J=19 \mathrm{~Hz}) \operatorname{ppm} .{ }^{31} \mathbf{P}\left\{{ }^{1} \mathbf{H}\right\} \mathbf{N M R}\left(202 \mathrm{MHz}, \mathrm{CDCl}_{3}\right): \delta-$ 17.84 (br) ppm. Anal. Calcd for $\mathrm{C}_{48} \mathrm{H}_{56} \mathrm{Cu}_{2} \mathrm{I}_{2} \mathrm{~N}_{2} \mathrm{O}_{4} \mathrm{P}_{2}$ : C, 49.37; H, 4.83; N, 2.40. Found: $\mathrm{C}$, 48.96; H, 4.31; N, 2.27.

\section{Synthesis of complex $\mathbf{2} \mathbf{P 4 A}$}

Copper(I) iodide (110 mg, $0.580 \mathrm{mmol}, 1$ equiv.) was reacted with phosphine 1d (200 mg, $0.580 \mathrm{mmol}, 1$ equiv. $)$ and pyridine $(0.93 \mathrm{~mL}, 11.6 \mathrm{mmol}, 20$ equiv. $)$ according to the general procedure previously mentioned to give a white solid (249 mg, yield 70\%). ${ }^{1} \mathbf{H}$ NMR (500 $\left.\mathrm{MHz}, \mathrm{CDCl}_{3}\right): \delta 8.68\left(\mathrm{~d}, 4 \mathrm{H}, \mathrm{CH}_{\mathrm{pyr}}, J=5 \mathrm{~Hz}\right), 7.69\left(\mathrm{tt}, 2 \mathrm{H}, \mathrm{CH}_{\mathrm{pyr}}, J=7 \mathrm{~Hz}, 2 \mathrm{~Hz}\right), \quad 7.65-7.50$ (m, 8H, $\left.\mathrm{CH}_{\mathrm{ph}}\right), 7.40-7.25\left(\mathrm{~m}, 16 \mathrm{H} \mathrm{CH}_{\mathrm{ph}}+\mathrm{CH}_{\mathrm{pyr}}\right), 3.49\left(\mathrm{~s}, 6 \mathrm{H}, \mathrm{CH}_{3}\right), 3.42\left(\mathrm{~s}, 6 \mathrm{H}, \mathrm{CH}_{3}\right), 3.29$ (br, 2H, CH), 2.83-2.50 (m, 8H, $\left.\mathrm{CH}_{2}\right)$ ppm. ${ }^{13} \mathbf{C}$ NMR (125 MHz, $\left.\mathrm{CDCl}_{3}\right): \delta 173.33,170.73$, $149.11,135.88,132.56,132.43,132.23,132.10,131.41,128.79(\mathrm{~d}, J=16 \mathrm{~Hz}) ; 127.51(\mathrm{dd}, J$ $=9 \mathrm{~Hz}, 5 \mathrm{~Hz}) ; 127.43,123.18,131.12,51.01,50.51,36.73(\mathrm{~d}, J=7 \mathrm{~Hz}) ; 35.59(\mathrm{~d}, J=6 \mathrm{~Hz})$; $27.49(\mathrm{~d}, J=14 \mathrm{~Hz})$ ppm. ${ }^{31} \mathbf{P}\left\{{ }^{1} \mathbf{H}\right\}$ NMR $\left(202 \mathrm{MHz}, \mathrm{CDCl}_{3}\right): \delta-17.8 \mathrm{ppm}$. Anal. Calcd for $\mathrm{C}_{48} \mathrm{H}_{52} \mathrm{Cu}_{2} \mathrm{I}_{2} \mathrm{~N}_{2} \mathrm{O}_{8} \mathrm{P}_{2}:$ C, 46.97; H, 4.27; N, 2.28. Found: C, 46.46; H, 4.05; N, 2.03 .

\section{Synthesis of complex $\mathbf{3}_{\mathbf{P 1}}$}

Copper(I) Iodide $(0.60 \mathrm{mmol})$, phosphine $(0.60 \mathrm{mmol})$ and dry toluene $(5 \mathrm{~mL})$ were placed in a flame-dried Schlenk tube under argon. The solution was heated at $100{ }^{\circ} \mathrm{C}$ during 24 hours. Then the mixture was cool down to room temperature and the solvent was removed under 
vacuum. The solid residue was dissolved in $\mathrm{CH}_{2} \mathrm{Cl}_{2}$ and the solution was poured into $\mathrm{Et}_{2} \mathrm{O}$. The complex precipitated instantaneously and was filtered and washed several times with $\mathrm{Et}_{2} \mathrm{O}$. The product was dried under vacuum (yield 92\%). Alternatively, complex $\mathbf{3}_{\mathbf{P} 1}$ could be obtained from complex $\mathbf{2}_{\mathbf{P 1 A}}$. Complex $\mathbf{2}_{\mathbf{P 1 A}}$ was dissolved in a minimum of ethyl acetate and then added to a silica gel chromatography using EtOAc/cyclohexane (8:2) to give compound 3P1 in quantitative yield. ${ }^{1} \mathbf{H}$ NMR $\left(500 \mathrm{MHz}, \mathrm{CDCl}_{3}\right): \delta 7.60\left(\mathrm{~m}, 16 \mathrm{H}, \mathrm{CH}_{\text {arom }}\right), 7.33(\mathrm{~m}, 8 \mathrm{H}$, $\mathrm{CH}_{\text {arom }}$ ), $7.20\left(\mathrm{~m}, 16 \mathrm{H}, \mathrm{CH}_{\text {arom }}\right), 2.61\left(\mathrm{~m}, 8 \mathrm{H}, \mathrm{CH}_{2} \mathrm{P}\right), 2.51\left(\mathrm{~m}, 8 \mathrm{H}, \mathrm{CH}_{2} \mathrm{CH}_{2} \mathrm{P}\right), 1.91(\mathrm{~s}, 12 \mathrm{H}$, $\left.\mathrm{CH}_{3}\right)$ ppm. ${ }^{13} \mathbf{C} \mathbf{N M R}\left(\mathrm{CDCl}_{3}, 125 \mathrm{MHz}\right): \delta, 207.57(\mathrm{~d}, J=15 \mathrm{~Hz}), 133.41(\mathrm{~d}, J=11 \mathrm{~Hz})$, 133.30, 130.04, $128.63(\mathrm{~d}, J=6 \mathrm{~Hz}), 38.84(\mathrm{~d}, J=6 \mathrm{~Hz}), 30.00,20.97$ (d, $J=17 \mathrm{~Hz}) \mathrm{ppm}$. ${ }^{31} \mathbf{P}\left\{{ }^{1} \mathbf{H}\right\}$ NMR (202 MHz, $\left.\mathrm{CDCl}_{3}\right) \delta$ : -29.5 ppm. FTIR: $\tilde{v}_{\max }$ (pure, diamond orbit) = 3053, $2912,1710,1575,1487,1434,1356,1215,1159,1099,868,739,693 \mathrm{~cm}^{-1}$. Anal. Calcd for $\mathrm{C}_{64} \mathrm{H}_{68} \mathrm{Cu}_{4} \mathrm{I}_{4} \mathrm{O}_{4} \mathrm{P}_{4}:$ C, 43.02; H, 3.84 Found: C, 43.61; H, 3.92.

\section{Photophysics}

Instrument details. Steady-state emission spectra were recorded on a Horiba Jobin-Yvon IBH FL-322 Fluorolog 3 spectrometer equipped with a $450 \mathrm{~W}$ xenon arc lamp, double-grating excitation, and emission monochromators $\left(2.1 \mathrm{~nm} \mathrm{~mm}^{-1}\right.$ of dispersion; 1200 grooves $\left.\mathrm{mm}^{-1}\right)$ and a Hamamatsu R13456 red sensitive Peltier-cooled PMT detector. Emission and excitation spectra were corrected for source intensity (lamp and grating) and emission spectral response (detector and grating) by standard correction curves. Time-resolved measurements were performed using either the Time-Correlated Single-Photon Counting (TCSPC) or the Multi Channel Scaling (MCS) electronics option of the TimeHarp 260 board installed on a PicoQuant FluoTime 300 fluorimeter (PicoQuant GmbH, Germany), equipped with a PDL 820 laser pulse driver. A pulsed laser diode LDH-P-C-375 $(\lambda=375 \mathrm{~nm}$, pulse full width at half maximum $<50 \mathrm{ps}$, repetition rate $200 \mathrm{kHz}-40 \mathrm{MHz}$ ) was used to excite the sample in 
burst mode and mounted directly on the sample chamber at $90^{\circ}$. The photons were collected by a PMA Hybrid-07 single photon counting detector. The data were acquired by using the commercially available software EasyTau II (PicoQuant GmbH, Germany), while data analysis was performed using the built-in software FluoFit (PicoQuant GmbH, Germany). All the PLQYs on solid state samples, both crystals and thin-films, were recorded at a fixed excitation wavelength by using a Hamamatsu Photonics absolute PLQY measurements system (C9920-02) equipped with L9700-01 CW Xenon light source (150 W), monochromator, integrating sphere, C7473 photonics multi-channel analyzer and employing the commercially available U6039-05 PLQY measurement software (Hamamatsu Photonics Ltd., Shizuoka, Japan). All measurements were repeated 5 times at the excitation wavelength $\lambda_{\text {exc }}=320$. Low temperature $(77 \mathrm{~K})$ PLQY were measured by using a calibrated quartz Dewar (Hamamatsu) filled with liquid $\mathrm{N}_{2}$.

Methods. For time resolved measurements, data fitting was performed by employing the maximum likelihood estimation (MLE) methods and the quality of the fit was assessed by inspection of the reduced $\chi^{2}$ function and of the weighted residuals. For multi-exponential decays, the intensity, namely $\mathrm{I}(t)$, has been assumed to decay as the sum of individual single exponential decays (Eqn. 1):

$$
I(t)=\sum_{i=1}^{n} \alpha_{i} \exp \left(-\frac{t}{\tau_{i}}\right)
$$

where $\tau$ are the decay times and $\alpha_{i}$ are the amplitudes of the components at $t=0$. In the tables, the percentages to the pre-exponential factors, $\alpha_{i}$, are listed upon normalization. Intensity average lifetimes were calculated by using the following equation (Eqn. 2): [67]

$$
\bar{\tau}=\frac{a_{1} \tau_{1}^{2}+a_{2} \tau_{2}^{2}}{a_{1} \tau_{1}+a_{2} \tau_{2}} \quad \text { (Eqn. 2) }
$$

Time resolved emission decay traces along with the fitting curves and residuals are reported as supplementary materials in Figure S33-S40. 


\section{Competing interests}

The authors declare no competing financial interests.

\section{References}

[1] O. S. Wenger, Photoactive Complexes with Earth-Abundant Metals, J. Am. Chem. Soc. 140 (2018) 13522-13533. https://doi.org/10.1021/jacs.8b08822.

[2] C. B. Larsen, O. S. Wenger, Photoredox Catalysis with Metal Complexes Made from Earth-Abundant Elements, Chem. Eur. J. 24 (2018) 2039-2058. https://doi.org/10.1002/chem.201703602.

[3] C. Förster, K. Heinze, Photophysics and photochemistry with Earth-abundant metals fundamentals and concepts, Chem. Soc. Rev. 49 (2020) 1057-1070. https://doi.org/10.1039/C9CS00573K.

[4] J. Twilton, C. Le, P. Zhang, M. H. Shaw, R. W. Evans, D. W. C. MacMillan, The merger of transition metal and photocatalysis, Nat. Rev. Chem. 1 (2017) 1-19. https://doi.org/10.1038/s41570-017-0052.

[5] A. Barbieri, G. Accorsi, N. Armaroli, Luminescent complexes beyond the platinum group: the d10 avenue, Chem. Commun. (2008) 2185-2193. https://doi.org/10.1039/B716650H.

[6] N. Armaroli, Photoactive mono- and polynuclear $\mathrm{Cu}(\mathrm{I})$-phenanthrolines. A viable alternative to $\mathrm{Ru}(\mathrm{II})$-polypyridines?, Chem. Soc. Rev. 30 (2001) 113-124. https://doi.org/10.1039/B000703J.

[7] M. Wallesch, D. Volz, D. M. Zink, U. Schepers, M. Nieger, T. Baumann, S. Bräse, Bright Coppertunities: Multinuclear CuI Complexes with N-P Ligands and Their Applications, Chem. Eur. J. $20 \quad$ (2014) 6578-6590. https://doi.org/10.1002/chem.201402060.

[8] P. C. Ford, E. Cariati, J. Bourassa, Photoluminescence Properties of Multinuclear Copper(I) Compounds, Chem. Rev. $99 \quad$ (1999) 3625-3648. https://doi.org/10.1021/cr960109i.

[9] A. Kobayashi, M. Kato, Stimuli-responsive Luminescent Copper(I) Complexes for Intelligent Emissive Devices, Chem. Lett. $46 \quad$ (2017) 154-162. https://doi.org/10.1246/cl.160794.

[10] R. Czerwieniec, M. J. Leitl, H. H. H. Homeier, H. Yersin, Cu(I) complexes - Thermally activated delayed fluorescence. Photophysical approach and material design, Coord. Chem. Rev. 325 (2016) 2-28. https://doi.org/10.1016/j.ccr.2016.06.016.

[11] a) R. Hamze, J. L. Peltier, D. Sylvinson, M. Jung, J. Cardenas, R. Haiges, M. Soleilhavoup, R. Jazzar, P. I. Djurovich, G. Bertrand, M. E. Thompson, Eliminating nonradiative decay in $\mathrm{Cu}(\mathrm{I})$ emitters: $>99 \%$ quantum efficiency and microsecond lifetime, Science. 363 (2019) 601-606. https://doi.org/10.1126/science.aav2865; b) J. Zhang, C. Duan, C. Han, H. Yang, Y. Wei, H. Xu, Balanced dual emission from 
tridentate phosphine-coordinate copper(I) complexes toward highly efficient yellow OLEDs, Adv. Mater., 2016, 28, 5975-5979, doi: 10.1002/adma.201600487.

[12] K. Tsuge, Y. Chishina, H. Hashiguchi, Y. Sasaki, M. Kato, S. Ishizaka, N. Kitamura, Luminescent copper(I) complexes with halogenido-bridged dimeric core, Coord. Chem. Rev. 306 (2016) 636-651. https://doi.org/10.1016/j.ccr.2015.03.022.

[13] S. Shi, M. C. Jung, C. Coburn, A. Tadle, D. Sylvinson M. R., P. I. Djurovich, S. R. Forrest, M. E. Thompson, Highly Efficient Photo- and Electroluminescence from TwoCoordinate $\mathrm{Cu}(\mathrm{I})$ Complexes Featuring Nonconventional N-Heterocyclic Carbenes, J. Am. Chem. Soc. 141 (2019) 3576-3588. https://doi.org/10.1021/jacs.8b12397.

[14] M. Elie, F. Sguerra, F. Di Meo, M. D. Weber, R. Marion, A. Grimault, J.-F. Lohier, A. Stallivieri, A. Brosseau, R. B. Pansu, J.-L. Renaud, M. Linares, M. Hamel, R. D. Costa, S. Gaillard, Designing NHC-Copper(I) Dipyridylamine Complexes for Blue LightEmitting Electrochemical Cells, ACS Appl. Mater. Interfaces. 8 (2016) 14678-14691. https://doi.org/10.1021/acsami.6b04647.

[15] D. M. Zink, D. Volz, T. Baumann, M. Mydlak, H. Flügge, J. Friedrichs, M. Nieger, S. Bräse, Heteroleptic, Dinuclear Copper(I) Complexes for Application in Organic LightEmitting Diodes, Chem. Mater. $25 \quad$ (2013) 4471-4486. https://doi.org/10.1021/cm4018375.

[16] M. Gernert, U. Müller, M. Haehnel, J. Pflaum, A. Steffen, A Cyclic Alkyl(amino)carbene as Two-Atom $\pi$-Chromophore Leading to the First Phosphorescent Linear CuI Complexes, Chem. Eur. J. 23 (2017) 2206-2216. https://doi.org/10.1002/chem.201605412.

[17] L. Maini, D. Braga, P. P. Mazzeo, B. Ventura, Polymorph and isomer conversion of complexes based on $\mathrm{CuI}$ and PPh3 easily observed via luminescence, Dalton Trans. 41 (2011) 531-539. https://doi.org/10.1039/C1DT11462J.

[18] D. Volz, M. Nieger, J. Friedrichs, T. Baumann, S. Bräse, How the Quantum Efficiency of a Highly Emissive Binuclear Copper Complex Is Enhanced by Changing the Processing Solvent, Langmuir. 29 (2013) 3034-3044. https://doi.org/10.1021/la3039522.

[19] M. W. Blaskie, D. R. McMillin, Photostudies of copper(I) systems. 6. Roomtemperature emission and quenching studies of bis(2,9-dimethyl-1,10phenanthroline)copper(I), Inorg. Chem. $19 \quad$ (1980) 3519-3522. https://doi.org/10.1021/ic50213a062.

[20] R. M. Everly, D. R. McMillin, Reinvestigation of the absorbing and emitting chargetransfer excited states of [Cu(NN)2]+ systems, J. Phys. Chem. 95 (1991) 9071-9075. https://doi.org/10.1021/j100176a011.

[21] J. R. Kirchhoff, R. E. Gamache, M. W. Blaskie, A. A. Del Paggio, R. K. Lengel, D. R. McMillin, Temperature dependence of luminescence from $\mathrm{Cu}(\mathrm{NN}) 2+$ systems in fluid solution. Evidence for the participation of two excited states, Inorg. Chem. 22 (1983) 2380-2384. https://doi.org/10.1021/ic00159a008.

[22] R. M. Everly, D. R. McMillin, Concentration-dependent lifetimes of $\mathrm{Cu}(\mathrm{NN})+2$ systems: exciplex quenching from the ion pair state, Photochem. Photobiol. 50 (1989) 711-716. https://doi.org/10.1111/j.1751-1097.1989.tb02900.x. 
[23] D. R. McMillin, J. R. Kirchhoff, K. V. Goodwin, Exciplex quenching of photo-excitd copper complexes, Coord. Chem. Rev. 64 (1985) 83-92. https://doi.org/10.1016/00108545(85)80043-6.

[24] H. Ohara, A. Kobayashi, M. Kato, Simple Manual Grinding Synthesis of Highly Luminescent Mononuclear Cu(I)-Iodide Complexes, Chem. Lett. 43 (2014) 1324-1326. https://doi.org/10.1246/cl.140443.

[25] H. Ohara, A. Kobayashi, M. Kato, Simple and extremely efficient blue emitters based on mononuclear $\mathrm{Cu}(\mathrm{I})$-halide complexes with delayed fluorescence, Dalton Trans. 43 (2014) 17317-17323. https://doi.org/10.1039/C4DT02709D.

[26] H. Ohara, A. Kobayashi, M. Kato, Effects of N-heteroaromatic ligands on highly luminescent mononuclear copper(I)-halide complexes, C. R. Chim. 18 (2015) 766-775. https://doi.org/10.1016/j.crci.2015.03.003.

[27] P. Liang, A. Kobayashi, T. Hasegawa, M. Yoshida, M. Kato, Thermal and Mechanochemical Syntheses of Luminescent Mononuclear Copper(I) Complexes, Eur. J. Inorg. Chem. 2017 (2017) 5134-5142. https://doi.org/10.1002/ejic.201700734.

[28] K. R. Kyle, C. K. Ryu, P. C. Ford, J. A. DiBenedetto, Photophysical studies in solution of the tetranuclear copper(I) clusters Cu4I4L4 ( $\mathrm{L}=$ pyridine or substituted pyridine), J. Am. Chem. Soc. 113 (1991) 2954-2965. https://doi.org/10.1021/ja00008a026.

[29] N. P. Rath, J. L. Maxwell, E. M. Holt, Fluorescent copper(I) complexes: an X-ray diffraction study of complexes of copper(I) iodide and pyridine derivatives of rhombic, [Cu2I2(3Me-py)4], and polymeric structure, [\{Cul(2me-py) $\} \infty]$ and $[\{\mathrm{Cul}(2,4 \mathrm{Me} 2-$ py) $\} \infty$ ], J. Chem. Soc., Dalton Trans. (1986) 2449-2453. https://doi.org/10.1039/DT9860002449.

[30] M. Henary, J. L. Wootton, S. I. Khan, J. I. Zink, Structure and Assignment of the Luminescence of a New Mixed-Ligand Copper(I) Polymer, Inorg. Chem. 36 (1997) 796-801. https://doi.org/10.1021/ic9610593.

[31] R.-Z. Li, D. Li, X.-C. Huang, Z.-Y. Qi, X.-M. Chen, A photoluminescent polymeric chain complex: synthesis and structure of $[(\mathrm{PPh} 3) 2 \mathrm{Cu} 2(\mu-\mathrm{I}) 2(\mu-4,4$ '-bpy $)] \mathrm{n}$, Inorg. Chem. Commun. 6 (2003) 1017-1019. https://doi.org/10.1016/S1387-7003(03)00170-9.

[32] H. Araki, K. Tsuge, Y. Sasaki, S. Ishizaka, N. Kitamura, Luminescence Ranging from Red to Blue: A Series of Copper(I)-Halide Complexes Having Rhombic $\{\mathrm{Cu} 2(\mu-\mathrm{X}) 2\}$ (X = Br and I) Units with N-Heteroaromatic Ligands, Inorg. Chem. 44 (2005) 96679675. https://doi.org/10.1021/ic0510359.

[33] K. Tsuge, Luminescent Complexes Containing Halogeno-bridged Dicopper(I) Unit $\mathrm{Cu}_{2}(\mu-\mathrm{X})_{2} \quad(\mathrm{X}=\mathrm{Cl}, \quad \mathrm{Br}$, and I), Chem. Lett. 42 (2013) 204-208. https://doi.org/10.1246/cl.2013.204.

[34] Y. Okano, H. Ohara, A. Kobayashi, M. Yoshida, M. Kato, Systematic Introduction of Aromatic Rings to Diphosphine Ligands for Emission Color Tuning of Dinuclear Copper(I) Iodide Complexes, Inorg. Chem. 55 (2016) 5227-5236. https://doi.org/10.1021/acs.inorgchem.6b00161.

[35] K. Shimada, A. Kobayashi, Y. Ono, H. Ohara, T. Hasegawa, T. Taketsugu, E. Sakuda, S. Akagi, N. Kitamura, M. Kato, Core-Structure-Dependent Luminescence of ThiolatoBridged Copper(I) Cluster Complexes, J. Phys. Chem. C. 120 (2016) 16002-16011. https://doi.org/10.1021/acs.jpcc.5b12688. 
[36] A. Kobayashi, K. Komatsu, H. Ohara, W. Kamada, Y. Chishina, K. Tsuge, H.-C. Chang, M. Kato, Photo- and Vapor-Controlled Luminescence of Rhombic Dicopper(I) Complexes Containing Dimethyl Sulfoxide, Inorg. Chem. 52 (2013) 13188-13198. https://doi.org/10.1021/ic402104q.

[37] A. Kobayashi, M. Fujii, Y. Shigeta, M. Yoshida, M. Kato, Quantitative Solvent-Free Thermal Synthesis of Luminescent $\mathrm{Cu}(\mathrm{I})$ Coordination Polymers, Inorg. Chem. 58 (2019) 4456-4464. https://doi.org/10.1021/acs.inorgchem.8b03641.

[38] T. Hayashi, A. Kobayashi, H. Ohara, M. Yoshida, T. Matsumoto, H.-C. Chang, M. Kato, Vapochromic Luminescence and Flexibility Control of Porous Coordination Polymers by Substitution of Luminescent Multinuclear $\mathrm{Cu}(\mathrm{I})$ Cluster Nodes, Inorg. Chem. 54 (2015) 8905-8913. https://doi.org/10.1021/acs.inorgchem.5b00578.

[39] D. Volz, D. M. Zink, T. Bocksrocker, J. Friedrichs, M. Nieger, T. Baumann, U. Lemmer, S. Bräse, Molecular Construction Kit for Tuning Solubility, Stability and Luminescence Properties: Heteroleptic MePyrPHOS-Copper Iodide-Complexes and their Application in Organic Light-Emitting Diodes, Chem. Mater. 25 (2013) 34143426. https://doi.org/10.1021/cm4010807.

[40] D. M. Zink, M. Bächle, T. Baumann, M. Nieger, M. Kühn, C. Wang, W. Klopper, U. Monkowius, T. Hofbeck, H. Yersin, S. Bräse, Synthesis, Structure, and Characterization of Dinuclear Copper(I) Halide Complexes with $\mathrm{P}^{\wedge} \mathrm{N}$ Ligands Featuring Exciting Photoluminescence Properties, Inorg. Chem. $52 \quad$ (2013) 2292-2305. https://doi.org/10.1021/ic300979c.

[41] K. R. Kyle, J. DiBenedetto, P. C. Ford, Dual photoemissions from the room temperature solutions of the tetranuclear copper(I) clusters Cu4I4(py-X)4(py-X = substituted pyridine), J. Chem. Soc., Chem. Commun. (1989) 714-715. https://doi.org/10.1039/C39890000714.

[42] F. De Angelis, S. Fantacci, A. Sgamellotti, E. Cariati, R. Ugo, P. C. Ford, Electronic Transitions Involved in the Absorption Spectrum and Dual Luminescence of Tetranuclear Cubane [Cu4I4(pyridine)4] Cluster: a Density Functional Theory/TimeDependent Density Functional Theory Investigation, Inorg. Chem. 45 (2006) 1057610584. https://doi.org/10.1021/ic061147f.

[43] M. Xie, C. Han, J. Zhang, G. Xie, H. Xu, White Electroluminescent Phosphine-Chelated Copper Iodide Nanoclusters, Chem. Mater. 29 (2017) 6606-6610. https://doi.org/10.1021/acs.chemmater.7b01443.

[44] a) H. Kitagawa, Y. Ozawa, K. Toriumi, Flexibility of cubane-like Cu4I4 framework: temperature dependence of molecular structure and luminescence thermochromism of [Cu4I4(PPh3)4] in two polymorphic crystalline states, Chem. Commun. 46 (2010) 6302-6304. https://doi.org/10.1039/C0CC01434F; b) M. Xie, C. Han, Q. Liang, J. Zhang, G. Xie, H. Xu, Sci. Adv., 2019, 5, eaav9857. DOI: 10.1126/sciadv.aav9857

[45] S. Perruchas, X. F. Le Goff, S. Maron, I. Maurin, F. Guillen, A. Garcia, T. Gacoin, J.-P. Boilot, Mechanochromic and Thermochromic Luminescence of a Copper Iodide Cluster, J. Am. Chem. Soc. 132 (2010) 10967-10969. https://doi.org/10.1021/ja103431d.

[46] S. Perruchas, C. Tard, X. F. Le Goff, A. Fargues, A. Garcia, S. Kahlal, J.-Y. Saillard, T. Gacoin, J.-P. Boilot, Thermochromic Luminescence of Copper Iodide Clusters: The 
Case of Phosphine Ligands, Inorg. Chem. 50 (2011) 10682-10692. https://doi.org/10.1021/ic201128a.

[47] S. Perruchas, N. Desboeufs, S. Maron, X. F. Le Goff, A. Fargues, A. Garcia, T. Gacoin, J.-P. Boilot, Siloxanol-Functionalized Copper Iodide Cluster as a Thermochromic Luminescent Building Block, Inorg. Chem. $51 \quad$ (2012) 794-798. https://doi.org/10.1021/ic200672r.

[48] B. Huitorel, Q. Benito, A. Fargues, A. Garcia, T. Gacoin, J.-P. Boilot, S. Perruchas, F. Camerel, Mechanochromic Luminescence and Liquid Crystallinity of Molecular Copper Clusters, Chem. $\quad$ Mater. $28 \quad$ (2016) 8190-8200. https://doi.org/10.1021/acs.chemmater.6b03002.

[49] Q. Benito, I. Maurin, M. Poggi, C. Martineau-Corcos, T. Gacoin, J.-P. Boilot, S. Perruchas, Impact of crystalline packing on the mechanochromic luminescence properties of copper based compounds: towards functional coatings, J. Mater. Chem. C. 4 (2016) 11231-11237. https://doi.org/10.1039/C6TC04262G.

[50] B. Huitorel, H. El Moll, R. Utrera-Melero, M. Cordier, A. Fargues, A. Garcia, F. Massuyeau, C. Martineau-Corcos, F. Fayon, A. Rakhmatullin, S. Kahlal, J.-Y. Saillard, T. Gacoin, S. Perruchas, Evaluation of Ligands Effect on the Photophysical Properties of Copper Iodide Clusters, Inorg. Chem. $57 \quad$ (2018) 4328-4339. https://doi.org/10.1021/acs.inorgchem.7b03160.

[51] D. Bissessar, J. Egly, T. Achard, P. Steffanut, S. Bellemin-Laponnaz, Catalyst-free hydrophosphination of alkenes in presence of 2-methyltetrahydrofuran: a green and easy access to a wide range of tertiary phosphines, RSC Adv. 9 (2019) 27250-27256. https://doi.org/10.1039/C9RA04896K.

[52] The $\Delta E_{\mathrm{S}-\mathrm{T}}$ has been estimated as energetic difference between the emission maxima at room temperature and $77 \mathrm{~K}$. An alternative method corresponds to determine the energy separation of the two spectra taken at the high-energy flank at $50 \%$ of the maximum intensity. See reference: M. J. Leitl, F.-R. Küchle, H. A. Mayer, L. Wesemann, H. Yersin, Brightly Blue and Green Emitting $\mathrm{Cu}(\mathrm{I})$ Dimers for Singlet Harvesting in OLEDs, J. Phys. Chem. A. 117 (2013) 11823-11836. https://doi.org/10.1021/jp402975d. In this way, the estimated $\Delta E_{\mathrm{S}-\mathrm{T}} \approx 1700 \mathrm{~cm}^{-1}(0.21 \mathrm{eV})$.

[53] A. Makal, J. Benedict, E. Trzop, J. Sokolow, B. Fournier, Y. Chen, J. A. Kalinowski, T. Graber, R. Henning, P. Coppens, Restricted Photochemistry in the Molecular Solid State: Structural Changes on Photoexcitation of $\mathrm{Cu}(\mathrm{I})$ Phenanthroline Metal-to-Ligand Charge Transfer (MLCT) Complexes by Time-Resolved Diffraction, J. Phys. Chem. A. 116 (2012) 3359-3365. https://doi.org/10.1021/jp300313s.

[54] L. Zhang, B. Li, Z. Su, Phosphorescence Enhancement Triggered by $\Pi$ Stacking in Solid-State $[\mathrm{Cu}(\mathrm{N}-\mathrm{N})(\mathrm{P}-\mathrm{P})] \mathrm{BF} 4 \quad$ Complexes, Langmuir. 25 (2009) 2068-2074. https://doi.org/10.1021/la803822s.

[55] E. Quartapelle Procopio, M. Mauro, M. Panigati, D. Donghi, P. Mercandelli, A. Sironi, G. D'Alfonso, L. De Cola, Highly Emitting Concomitant Polymorphic Crystals of a Dinuclear Rhenium Complex, J. Am. Chem. Soc. 132 (2010) 14397-14399. https://doi.org/10.1021/ja106772v.

[56] M. Brinkmann, G. Gadret, M. Muccini, C. Taliani, N. Masciocchi, A. Sironi, Correlation between Molecular Packing and Optical Properties in Different Crystalline Polymorphs 
and Amorphous Thin Films of mer-Tris(8-hydroxyquinoline)aluminum(III), J. Am. Chem. Soc. 122 (2000) 5147-5157. https://doi.org/10.1021/ja993608k.

[57] J. S. Field, L. P. Ledwaba, O. Q. Munro, D. R. McMillin, Crystal structures and photoluminescent properties of the orange and yellow forms of $\left[\mathrm{Pt}\left\{4^{\prime}-(\mathrm{O}-\right.\right.$ ClC6H4)trpy $\}(\mathrm{CN})$ ]SbF6: an example of concomitant polymorphism, CrystEngComm. 10 (2008) 740-747. https://doi.org/10.1039/B717655D.

[58] A. Aliprandi, M. Mauro, L. De Cola, Controlling and imaging biomimetic self-assembly, Nat. Chem. 8 (2016) 10-15. https://doi.org/10.1038/nchem.2383.

[59] Q. Benito, X. F. Le Goff, G. Nocton, A. Fargues, A. Garcia, A. Berhault, S. Kahlal, J.-Y. Saillard, C. Martineau, J. Trébosc, T. Gacoin, J.-P. Boilot, S. Perruchas, Geometry Flexibility of Copper Iodide Clusters: Variability in Luminescence Thermochromism, Inorg. Chem. 54 (2015) 4483-4494. https://doi.org/10.1021/acs.inorgchem.5b00321.

[60] A. Bondi, van der Waals Volumes and Radii, J. Phys. Chem. 68 (1964) 441-451. https://doi.org/10.1021/j100785a001.

[61] “Kappa CCD Operation Manual”, Nonius B. V., Ed. ; Delft: The Netherlands (1997).

[62] G. M. Sheldrick, Phase annealing in SHELX-90: direct methods for larger structures, Acta Cryst A. 46 (1990) 467-473. https://doi.org/10.1107/S0108767390000277.

[63] G. M. Sheldrick, A short history of SHELX, Acta Cryst A. 64 (2008) 112-122. https://doi.org/10.1107/S0108767307043930.

[64] A. L. Spek, Single-crystal structure validation with the program PLATON, J Appl Cryst. 36 (2003) 7-13. https://doi.org/10.1107/S0021889802022112.

[65] "M86-E01078 APEX2 User Manual”, Bruker AXS Inc., Madison, USA (2006).

[66] G. Sheldrick, (1999) “SHELXL-97”, Universität Göttingen, Göttingen, Germany.

[67] J. R. Lakowicz, Principles of Fluorescence Spectroscopy, 3rd ed., Springer US, 2006. https://doi.org/10.1007/978-0-387-46312-4. 